\title{
Accelerated phosphorus removal using sulfate-coated expanded vermiculite
}

\author{
Taeyoon Lee ${ }^{1}$ \\ ${ }^{1}$ Faculty of Environmental Engineering, Pukyong National University, Busan, Korea
}

This study evaluated whether phosphorus in an aqueous solution can be effectively adsorbed and removed by sulfuric acid (SA)-coated vermiculite (SCV), which was synthetized by heating a mixture of expanded vermiculite (EV) and $\mathrm{SA}$ at $300^{\circ} \mathrm{C}$. Phosphorus was removed from the aqueous solution and removal characteristics were evaluated by batch kinetic, batch adsorption, and column tests. The phosphate removal rates $\left(\mathrm{h}^{-1}\right)$ for $1,2.5,5,7.5,12.5$, and $25 \mathrm{~g} \cdot \mathrm{L}^{-1}$ of SCV were $0.00015,0.0011,0.0044,0.0087,0.0648$, and 0.5002 , respectively. The $Q_{\max }$ of the Langmuir model and the partition coefficients of the linear and Freundlich models were $8.92 \mathrm{mg} \cdot \mathrm{g}^{-1}, 0.65 \mathrm{~L} \cdot \mathrm{g}^{-1}$, and $4.60 \mathrm{~L} \cdot \mathrm{g}^{-1}(1 / \mathrm{n}=0.354)$, respectively. The equilibrium phosphorus adsorptions $\left(q_{e}\right)$ were $7.47,14.69$, and $19.53 \mathrm{mg} \cdot \mathrm{g}^{-1}$ at initial concentrations of 10,25 , and $50 \mathrm{mg} \cdot \mathrm{L}^{-1}$, respectively. These results show that SCV can efficiently adsorb phosphorus in an aqueous solution.

\section{INTRODUCTION}

Domestic sewage, industrial wastewater, fertilizers, and livestock excretions lead to excessive accumulation of nutrient salts in drainage basins that can lead to eutrophication, deteriorating water quality, and other negative environmental effects (De-Bashan and Bashan, 2004; Song et al., 2007; Guan et al., 2009; Saha et al., 2008; Awual and Jyo, 2011; Huang et al., 2015). Eutrophication promotes abnormal growth of phytoplankton such as algae and eventually leads to death of fish and other aquatic organisms by exhausting dissolved oxygen (Estrada et al., 2011; Yang et al., 2013; Cabrita et al., 2015; Lapointe et al., 2015; Tekile et al., 2015). Water may smell foul when vegetation and algae decompose, and its turbidity also increases (Estrada et al., 2011; Yang et al., 2013). The eutrophication process can produce environmental toxins such as microcystins that can be ingested by humans (Codd et al., 2005; Yuan et al., 2006; Dittmann and Wiegand, 2006).

Excessive nutrients, such as nitrogen and phosphorus, must be removed from lakes and rivers to prevent eutrophication; however, the phosphorus usually occurs in aqueous form with limited sources and a relatively low influx compared to nitrogen. Thus, it is termed a limiting nutrient source and its removal is the most efficient way of preventing eutrophication in lakes and rivers (Zeng et al., 2004; Biswas et al., 2007; Kim et al., 2008; Lurling and Oosterhout, 2013; Lurling et al., 2014; Ogata et al., 2015). Phosphorus can be eliminated by physical, chemical, and biological methods. Current physical methods are microfiltration (Lu and Liu, 2010), reverse osmosis (Kartashevsky et al., 2015), and electrodialysis; chemical methods include precipitation, crystallization (Oladoja et al., 2013), cation exchange (Ruixia et al., 2002), and adsorption (Yang et al., 2013; Karaca et al., 2004; Choi et al., 2012); and biological methods are anaerobic-aerobic-activated sludge processing and enhanced biological phosphorus removal (Munch and Barr, 2001; Vaiopoulou and Melidis, 2007). The physical methods are generally easy and stable but costly (Nguyen et al., 2014). Electrodialysis and reverse osmosis have low efficiency, with removal of just $10 \%$ of total phosphorus (Karaca et al., 2004). Precipitation produces additional sludge that creates treatment and disposal issues and has high chemical treatment costs (De-Bashan and Bashan, 2004; Ruixia et al., 2002; Kumar et al., 2010; Zhang et al., 2011). The biological methods also have disadvantages. They are dependent on favourable microbial environmental conditions and require considerable space to complete treatment, making it difficult to implement continuous and stable treatments (Nguyen et al., 2014; Jung et al., 2000; Ning et al., 2008).

The adsorption method is convenient in comparison to the physical, chemical, and biological methods. It is economical, with a high selectivity for phosphorus that can increase removal rates at lower costs (Yang et al., 2013; Karaca et al., 2004; Zhang et al., 2011); furthermore, because it is possible to apply adsorption to water of varying quality, it can be widely applied. A variety of low-cost adsorbents for the removal of phosphorus have been developed using industrial by-products such as red mud (Akay et al., 1998), dolomite (Karaca et al., 2004), fly ash (Guan et al., 2009; Cheung and Venkitachalam, 2000; Wen et al., 2014), olivine (Lee and Yim, 2011), steel slag (Bowden et al., 2009), and zirconium (Biswas et al., 2008).

The vermiculite used in this study is a clay mineral composed of magnesium, iron, and aluminium, with a 2:1 combination structure between tetrahedral-silica and octahedral-alumina sheets. The mineral has a high cation exchange ratio of $120-150 \mathrm{meq} \cdot 100 \mathrm{~g}^{-1}$ from the ion exchange between the surface and internal areas, and heating of $800 \sim 1,100^{\circ} \mathrm{C}$ results in expansion of about 6-20 times, turning it into a porous media with a large specific surface area that allows it to float on water (Malandrino et al., 2006; Song et al., 2009). In addition, because vermiculite is abundant and low-cost, it can be applied as a filter adsorbent on roads during rainstorms or be used as a natural adsorbent (Kim and Lee, 2014).

\section{CORRESPONDENCE}

Taeyoon Lee

\section{EMAIL}

badger74w@pknu.ac.kr

\section{DATES}

Received: 18 February 2019 Accepted: 14 August 2020

\section{KEYWORDS}

vermiculite sulfuric acid floating adsorbent adsorption exfoliation phosphorus

\section{COPYRIGHT}

(c) The Author(s) Published under a Creative Commons Attribution 4.0 International Licence (CC BY 4.0) 
Many heterogeneous catalysis adsorbents have been made based on vermiculite for removal of various water pollutants, such as chitosan/vermiculite biocomposite (Chen et al., 2017), amphoteric modified vermiculite (Liu et al., 2017), amphoteric surfactant activated montmorillonite (Liu et al., 2016), and peroxymonosulfate activated with $\mathrm{Fe}^{0}$-montmorillonite (Yang et al., 2018).

Because all surface-coating adsorbent methods are not equally efficient in removing phosphorus, research continues to explore methods to increase sorption efficiency. Choi et al. (2012) reported the use of zeolite and activated alumina coated by sulfuric acid (SA); however, to our knowledge, no study has been done on the use of SA-coated vermiculite (SCV) for the removal of phosphorus. Anionization of adsorbents using sulfuric acid enables adsorbents to have a negative charge by combining sulfate ions with adsorbents. Common chemicals used for the anionization are $\left(\mathrm{NH}_{4}\right)_{2} \mathrm{SO}_{4}$ and $\mathrm{H}_{2} \mathrm{SO}_{4}$.

In general, cations such as $\mathrm{Ca}^{2+}, \mathrm{Mg}^{2+}, \mathrm{Al}^{3+}, \mathrm{Fe}^{3+}, \mathrm{K}^{+}, \mathrm{Na}^{+}$included in clay-type adsorbents leach from tetrahedral and octahedral layers when the adsorbents react with sulfuric acid, and $\mathrm{H}^{+}$ions substitute for leached cations (Del Gastillo and Grange, 1997). From this reaction, acidity of clay-type adsorbents increases. This reaction is expressed as follows.

$$
n H^{+}+A^{n+}-\text { clay }=A^{n+}+n H^{+}-\text {clay }
$$

where $A$ indicates cations in clay-type adsorbents.

Combination of adsorbents and anions in water easily occurs in clay-type adsorbents (for example, vermiculite) containing hydroxide $\left(\mathrm{OH}^{-}\right)$ions. The reaction of a combination of clay-type adsorbents and anions is represented as follows (McBride, 1994):

$$
>\mathrm{S}-\mathrm{OH}+A^{n-} \Rightarrow>\mathrm{S}-A^{(n-1)-}+\mathrm{OH}^{-}
$$

where $A^{n-}$ is anion in water and $>\mathrm{S}-\mathrm{OH}$ represents a metal hydroxyl group.

This ligand exchange reaction occurs effectively at low $\mathrm{pH}$. Thus, the activity of clay-type adsorbents should be lower according to Eq. 1.

When sulfuric acid is used with the clay-type adsorbents to promote the ligand exchange reaction, the reaction is expressed as follows (McBride, 1994):

$$
>\mathrm{S}-\mathrm{OH}+\mathrm{SO}_{4}{ }^{2-} \Rightarrow \mathrm{S}-\mathrm{O}-\mathrm{SO}_{3}^{-}+\mathrm{OH}^{-}
$$

Cations in clay-type adsorbents are replaced by $\mathrm{H}^{+}$ions and $\mathrm{SO}_{4}{ }^{2}$ is bonded to the clay-type adsorbents in the form of $\mathrm{SO}_{3}$.

Anion exchange of $\mathrm{SO}_{3}^{-}$in clay-type adsorbents with phosphorus in water occurs according to differences in shared charge among $\mathrm{SO}_{3}$ - or phosphorus with metal hydroxyl groups. In general, lower shared charge indicates higher binding force with anion and metal hydroxyl groups. Clay-type adsorbents containing $\mathrm{SO}_{3}^{-}$show greater shared charge on metal hydroxyl groups than that of $\mathrm{PO}_{4}^{3-}$ on metal hydroxyl groups. Thus, $\mathrm{SO}_{3}$ in the adsorbents can be easily replaced by $\mathrm{PO}_{4}{ }^{3-}$ in wastewater (McBride, 1994).

Here we report the results of surface characteristics of SCV and results of phosphorus removal by SCV. Elemental scanning electron microscopy and energy dispersive $\mathrm{x}$-ray spectroscopy (SEM-EDS), $\mathrm{x}$-ray fluorescence (XRF), $\mathrm{x}$-ray powder diffraction (XRD), and Fourier transform infrared spectroscopy (FTIR) analyses were performed to evaluate the surface characteristics of SCV, and the adsorption capacity of SCV for phosphorus was determined using batch kinetic, batch sorption, and flow-through column tests.

\section{MATERIALS AND METHODS}

\section{Materials}

Vermiculite expanded about 15 times (Samhwa, Kwangjoo, Korea) was washed with DI water, and then stored in a desiccator until use. Vermiculite particles less than $3 \mathrm{~mm}$ diameter were used.

$\mathrm{H}_{2} \mathrm{SO}_{4}$ (95\% purity; Junsei Chemical, Japan) was used as the reagent for the SA coating. $\mathrm{KH}_{2} \mathrm{PO}_{4}$ (99\% purity) was obtained from Junsei Chemical Corporation (Junsei, Japan). $0.439 \mathrm{~g}$ of $\mathrm{KH}_{2} \mathrm{PO}_{4}$ was dissolved in $1 \mathrm{~L}$ of DI water to make $100 \mathrm{mg} \cdot \mathrm{L}^{-1} \mathrm{PO}_{4}{ }^{3-}$. The phosphorus solution was prepared by using $100 \mathrm{mg} \cdot \mathrm{L}^{-1} \mathrm{PO}_{4}{ }^{3-}$ for the phosphorus-adsorption experiment, and the concentration of phosphorus after reaction was measured by a DR900 Colorimeter (HACH, USA). A $0.45-\mu \mathrm{m}$ Teflon syringe filter was used to filter all samples before measurement.

\section{Production of adsorbents}

Bulk dry density was determined using a DME-220HE tuning fork density meter (Shinko Denshi Co., Japan).

The SCV was synthetized by mixing $50 \mathrm{~g}$ of EV and $500 \mathrm{~mL}$ of $10 \%$ $\mathrm{H}_{2} \mathrm{SO}_{4}$ in a $1 \mathrm{~L}$ glass beaker as described by Choi et al. (2012). After reacting the mixture at room temperature for $12 \mathrm{~h}$, the mixture was removed and heated in an electro-furnace (CT-DMF 1; Coretech, Korea) at $300^{\circ} \mathrm{C}$ for $3 \mathrm{~h}$ and then dried in an oven at $105^{\circ} \mathrm{C}$. The drying matter was cleaned 5 times with distilled water until no further $\mathrm{pH}$ change was observed in DI water.

The quantities of $\mathrm{C}, \mathrm{H}, \mathrm{N}$, and $\mathrm{S}$ in the EV and SCV were analysed by macro- and micro-elemental analysers (Elementar, Germany). Surface properties of EV and SCV were measured by SEM (S-2700; Hitachi, Japan). Oxide forms of EV and SCV were analysed by qualitative and quantitative analyses by XRF (XRF1700; Shimadzu Scientific Instruments, Japan) and XRD (X'PertMPD System; Philips, Netherlands) was used to observe the crystal structure of the SCV. The spectra according to the molecular structure and molecular binding of the compounds were analysed using FTIR (Spectrum X; Perkin Elmer, USA).

\section{Batch kinetic tests}

Batch kinetic tests were performed to evaluate the removal rate of phosphorus in the presence of varying doses of adsorbents under different initial phosphorus concentrations. Designated doses of adsorbents were placed in $50-\mathrm{mL}$ Teflon bottles filled with phosphorus solution $(40 \mathrm{~mL})$. The bottles were loaded on a shaker and rotated at $30 \mathrm{r} \cdot \mathrm{min}^{-1}$. Bottles were removed from the shaker intermittently for analysis. The sample was filtered through a 0.45-um Teflon syringe filter and prepared for analysis.

A first-order decay model with instantaneous adsorption was used to determine the bulk reaction rate constant $\left(K_{\text {obs }}\right)$ and the instantaneous partition coefficient $\left(K_{p}\right)$ for phosphorus. The model is (Koppensteiner, 1998):

$$
C_{a q}=\frac{C_{o}}{1+\frac{m}{v} K_{p}} \exp \left(\frac{-K_{o b s} \cdot t}{1+\frac{m}{v} K_{p}}\right)
$$

where $C_{\text {aq }}$ represents the phosphorus concentration $\left(\mathrm{mg} \cdot \mathrm{L}^{-1}\right)$ at a specific time, $C_{\mathrm{o}}$ is the initial phosphorus concentration $\left(\mathrm{mg} \cdot \mathrm{L}^{-1}\right)$, $m$ is the mass of sorbent $(\mathrm{g}), v$ is the volume of phosphorus

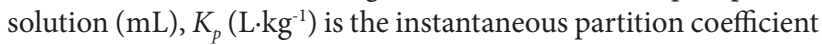
for phosphorus and $K_{\mathrm{obs}}$ is a bulk first-order reaction rate constant $\left(\mathrm{h}^{-1}\right)$. Equation 1 was fitted to the data using a least-squares algorithm.

The data obtained from the batch kinetic tests were analysed using the pseudo first-order and second-order kinetic models. 
The pseudo first-order kinetic model provided is expressed as Eq. 5.

$$
\log \left(q_{e}-q_{t}\right)=\log q_{e}-k_{1} t
$$

where $q_{e}\left(\mathrm{mg} \cdot \mathrm{g}^{-1}\right)$ and $q_{t}\left(\mathrm{mg} \cdot \mathrm{g}^{-1}\right)$ are the phosphate adsorbed amount at equilibrium and time $t$, respectively, and $k_{1}$ is the rate constant for the pseudo first-order kinetic model $\left(\mathrm{min}^{-1}\right)$. The pseudo second-order kinetic model is expressed as Eq. 6.

$$
\frac{t}{q_{t}}=\frac{1}{k_{2} q_{e}^{2}}+\frac{t}{q_{e}}
$$

where $k_{2}$ is the rate constant for the pseudo second-order kinetic model $\left(\mathrm{g} \cdot \mathrm{mg}^{-1} \cdot \mathrm{min}^{-1}\right)$. The values of $k_{2}$ and $q_{e}$ are calculated from a plot of $\left(t / q_{t}\right)$ versus $t$.

\section{Batch adsorption tests}

For the batch adsorption tests, the amount of adsorbent was maintained at a constant $(0.2 \mathrm{~g})$ while the initial concentration of phosphorus was varied from 10 to $50 \mathrm{mg} \cdot \mathrm{L}^{-1}$. Solution $\mathrm{pHs}$ for the batch and column tests were adjusted to 7.8 using $\mathrm{NaOH}$ and all the tests were performed at $23^{\circ} \mathrm{C}$. Phosphorus solutions $(40 \mathrm{~mL})$ and adsorbent were placed into $50-\mathrm{mL}$ bottles. The bottles were shaken at $30 \mathrm{r} \cdot \mathrm{min}^{-1}$ for $6 \mathrm{~h}$. After tumbling, the bottles were centrifuged at $8000 \mathrm{r} \cdot \mathrm{min}^{-1}(8200 \mathrm{~g})$ for $20 \mathrm{~min}$. Samples were obtained from the bottles using a 5-mL gas-tight syringe, and then prepared for analysis as described previously.

A simple isothermal equation (i.e., those of the linear, Freundlich, and Langmuir isotherm models) was used to generate an adsorption isotherm to indicate the adsorption equilibrium of a single ingredient. Adsorption parameters for phosphorus were obtained by fitting linear (Eq. 7), Freundlich (Eq. 8), and Langmuir models (Eq. 9) to the data using a least-squares algorithm. These models are as follows:

$$
\begin{gathered}
C_{s}=K_{p} C_{e} \\
C_{s}=K_{f} C_{e}^{1 / n} \\
C_{s}=\frac{Q_{\max } K_{l} C_{e}}{1+K_{l} C_{e}}
\end{gathered}
$$

where $C_{s}$ is the concentration $\left(\mathrm{mg} \cdot \mathrm{g}^{-1}\right.$ ) of phosphorus that was adsorbed on the adsorbent, $C_{e}$ is the equilibrium phosphorus concentration $\left(\mathrm{mg} \cdot \mathrm{L}^{-1}\right), K_{p}$ is the distribution coefficient of the linear model, and $K_{f}\left(\mathrm{~L} \cdot \mathrm{g}^{-1}\right), 1 / n$ are the Freundlich partition coefficient and adsorption constants related to the adsorption capacity and the intensity of adsorption, respectively. $Q_{\max }$ represents the maximum adsorption capacity $\left(\mathrm{mg}^{-\mathrm{g}^{-1}}\right)$, and $K_{\mathrm{l}}$ is a Langmuir adsorption constant related to the binding strength.

\section{Leaching of $\mathrm{SO}_{4}{ }^{2-}$ from SCV}

Additional batch kinetic tests were performed to determine leaching characteristics of $\mathrm{SO}_{4}^{2-}$ from $\mathrm{SCV}$ during phosphorus removal tests. The tests were performed under conditions of SCV $25 \mathrm{~g} \cdot \mathrm{L}^{-1}$ and initial phosphorus concentrations of $40 \mathrm{mg} \cdot \mathrm{L}^{-1}$. During the first tests, $\mathrm{SO}_{4}{ }^{2-}$ and phosphorus were measured at designated sampling times. After the first test, SCV was filtered and dried at $80^{\circ} \mathrm{C}$ in a drying oven for $12 \mathrm{~h}$. Then, the SCV was used for the second test under the condition of SCV $25 \mathrm{~g} \cdot \mathrm{L}^{-1}$ and initial phosphorus concentration of $40 \mathrm{mg} \cdot \mathrm{L}^{-1} \mathrm{SO}_{4}{ }^{2-}$ and phosphorus were also measured at designated sampling times. The third experiment was conducted in the same way as the second experiment.

\section{Column tests}

Column tests were conducted to determine sorbent efficiency of phosphorus in flow-through conditions. A schematic of the column test setup is shown in Fig. 1. A glass column (length $=300 \mathrm{~mm}$, diameter $=55 \mathrm{~mm}$ ) was used with Teflon adapters and porous

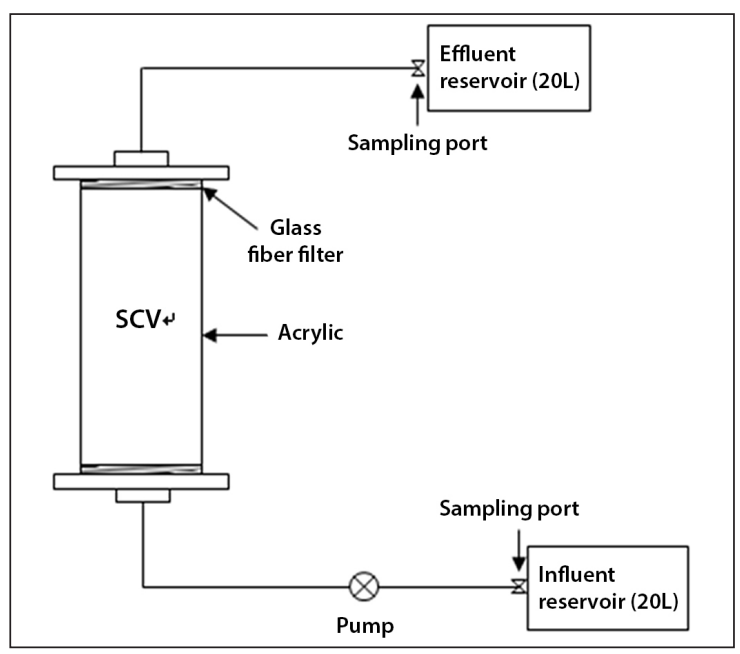

Figure 1. Schematic diagram of upward flow column test set-up

ceramic disks attached to both ends. $79.1 \mathrm{~g}$ of SCV was packed in the column (porosity $=0.42$ ). Prior to the start of the experiment, $200 \mathrm{~mL}$ of DI water was added to the column to saturate the inside of the column with DI water. The influent solution was then switched to a phosphorus solution for the column test.

Solution was introduced into the column at a constant flow rate using a peristaltic pump (model BT100-1F; LongerPump, USA). All tests were conducted with upward flow. Concentrations of phosphorus in the influent were set as 10,25 , and $50 \mathrm{mg} \cdot \mathrm{L}^{-1}$.

The adsorbed phosphorus quantity in the column $\left(q_{\text {total }}, \mathrm{mg}\right)$ can be expressed by Eq. 10, as follows:

$$
q_{\text {total }}=\frac{Q}{1000} \int_{t=0}^{t=t o t a l} C_{a} d_{t}
$$

where $C_{a}$ represents the adsorbed phosphorus concentration $\left(\mathrm{mg} \cdot \mathrm{L}^{-1}\right)$, which is calculated by $C_{\mathrm{o}}-C_{t}$ and $Q$ is the inflow flow rate $\left(\mathrm{mL} \cdot \mathrm{min}^{-1}\right)$; in addition, the equilibrium adsorbed quantity $q_{e}\left(\mathrm{mg}^{-1}\right)$ is shown in Eq. 11, as follows:

$$
q_{e}=\frac{q_{\text {total }}}{m}
$$

where $m$ represents the mass of vermiculite $(\mathrm{g})$ loaded in the column, and $C_{o}, C_{t}$ is the initial concentration and concentration measured at time $t$.

Empty bed contact time (EBCT) of column tests is calculated as follows:

$$
\text { EBCT }(\mathrm{min})=\text { bed volume }(\mathrm{mL}) / \text { flowrate }\left(\mathrm{mL} \cdot \mathrm{min}^{-1}\right)
$$

\section{RESULTS AND DISCUSSION}

\section{Elemental analysis of adsorbents}

The dry density of the EV was $0.25 \mathrm{~g} \cdot \mathrm{cm}^{-3}$ and a similar dry density was obtained for SCV $\left(0.26 \mathrm{~g} \cdot \mathrm{cm}^{-3}\right)$. The values of the elemental analysis for the $\mathrm{EV}$ and SCV are summarized in Table 1. The $\mathrm{C}$ and $\mathrm{N}$ concentrations of both the EV and SCV were similar: $0.22 \%$ and $0.20 \%(\mathrm{C})$ and $0.49 \%$ and $0.79 \%(\mathrm{~N})$, for $\mathrm{EV}$ and SCV, respectively; however, the concentrations of $\mathrm{H}$ and $\mathrm{S}$ were considerably different. $\mathrm{H}$ concentrations of EV and SCV were $0.75 \%$ and $1.29 \%$, and those of S were $0.28 \%$ and $5.68 \%$, respectively. The large difference in the $\mathrm{H}$ and $\mathrm{S}$ concentrations could be related to the addition of sulfate $\left(\mathrm{SO}_{4}{ }^{2-}\right)$ during coating.

Table 1. Elementary analysis of EV and SCV

\begin{tabular}{lcccc}
\hline Adsorbent & \multicolumn{4}{c}{ Elemental analyses (wt, \%) } \\
\cline { 2 - 5 } & $\mathrm{C}$ & $\mathrm{H}$ & $\mathrm{N}$ & $\mathrm{S}$ \\
\hline EV & 0.22 & 0.752 & 0.49 & 0.281 \\
SCV & 0.20 & 1.289 & 0.79 & 5.683 \\
\hline
\end{tabular}


Table 2. Chemical compositions of EV and SCV determined by x-ray fluorescence

\begin{tabular}{lccccccccccc}
\hline Adsorbent & $\mathrm{SiO}_{2}$ & $\mathrm{Al}_{2} \mathrm{O}_{3}$ & $\mathrm{MgO}$ & $\mathrm{Fe}_{2} \mathrm{O}_{3}$ & $\mathrm{CaO}$ & $\mathrm{K}_{2} \mathrm{O}$ & $\mathrm{TiO}_{2}$ & $\mathrm{SO}_{3}$ & $\mathrm{Na}_{2} \mathrm{O}$ & $\mathrm{Cr}_{2} \mathrm{O}_{3}$ & $\mathrm{NiO}$ \\
\hline $\mathrm{EV}$ & 44.41 & 12.49 & 27.2 & 4.96 & 1.38 & 5.96 & 1.44 & 0.08 & 1.29 & 0.38 & 0.06 \\
$\mathrm{SCV}$ & 43.14 & 8.92 & 18.85 & 4.01 & 0.48 & 5.46 & 1.52 & 16.87 & 0.37 & 0.31 & 0.04 \\
\hline
\end{tabular}

\section{XRF and XRD analyses of adsorbents}

Table 2 indicates the XRF results for EV and SCV. EV mainly consisted of $\mathrm{SiO}_{2}, \mathrm{MgO}$, and $\mathrm{Al}_{2} \mathrm{O}_{3}(44.4 \%, 27.2 \%$, and $12.5 \%$, respectively). The percentages of $\mathrm{SiO}_{2}$ and $\mathrm{K}_{2} \mathrm{O}(43.14 \%$ and $5.46 \%$ ) in SCV were similar for EV. SCV consisted of $18.9 \% \mathrm{MgO}$, $8.9 \% \mathrm{Al}_{2} \mathrm{O}_{3}$, and $4.0 \% \mathrm{Fe}_{2} \mathrm{O}_{3}$. All percentages of oxides in SCV decreased, with the exception of $\mathrm{SO}_{3}$, which increased to $16.9 \%$.

These results mean that the $\mathrm{K}^{+}$ion was not affected by the ion exchange of other metal cations or the metal complex, even with

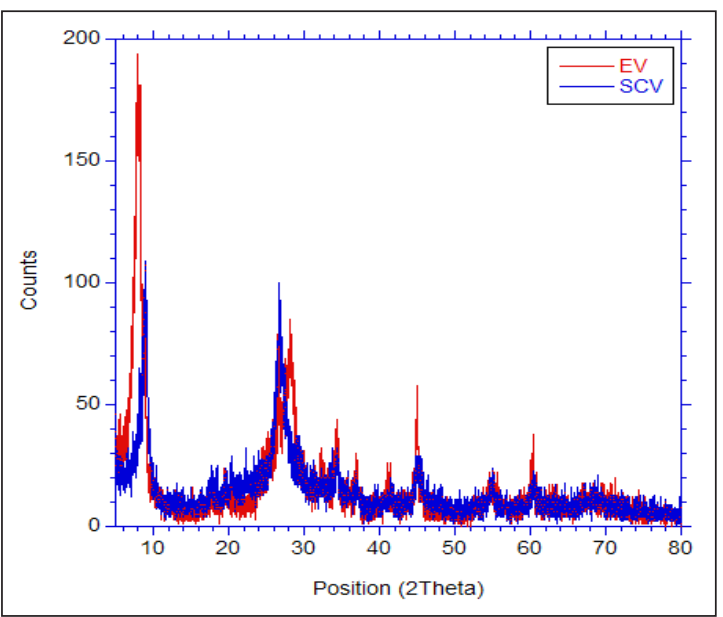

Figure 2. XRD pattern of $\mathrm{EV}$ and SCV the SA coating on $\mathrm{EV}$, and that the $\mathrm{K}^{+}$ion in $\mathrm{EV}$ was not involved in the ion exchange due to the primary involvement of the biotite layer (Muiambo et al., 2015). In addition, the quantity of $\mathrm{CaO}$ in EV and SCV decreased from $1.38 \%$ to $0.48 \%$, which can be explained by the substitution of the considerable quantity of $\mathrm{Ca}^{2+}$ ions between the vermiculite layers with $\mathrm{H}^{+}$.

Figure 2 shows results of the XRD analysis. EV had the highest peaks at $2 \theta\left(8.01^{\circ}, 28.09^{\circ}\right.$, and $\left.44.93^{\circ}\right)$, as did SCV $\left(9.03^{\circ}\right.$ and $\left.26.61^{\circ}\right)$; the $\mathrm{EV} 8.01^{\circ}$ peak represents a mica impurity in the vermiculite and the $44.93^{\circ}$ peak is caused by aluminium (Medeiros et al., 2009; Sousa et al., 2012). From Fig. 2, it is assumed the crystallization was weakened by the greater decrease of the SCV reflection intensity compared with that of $\mathrm{EV}$, but its original structure was not greatly changed.

\section{SEM-EDS analysis of adsorbents}

Figure 3 shows the SEM images for EV and SCV. In Fig. 3a, the smooth EV surface appears as a laminated structure with an accordion-like layer. The SCV surface is shown in Fig. 3b, and a modification between the surface and a vermiculite layer from heating to a high temperature is evident. Figure $3 \mathrm{c}$ shows the surface of SCV after adsorption tests are performed. In the case of EV, the surface was smooth, but in the case of SCV, it was confirmed that many cracks were formed on the surface. Since many particles were formed on the surface of the SCV after the adsorption experiment, it is judged to be a change due to the adsorption of phosphorus.

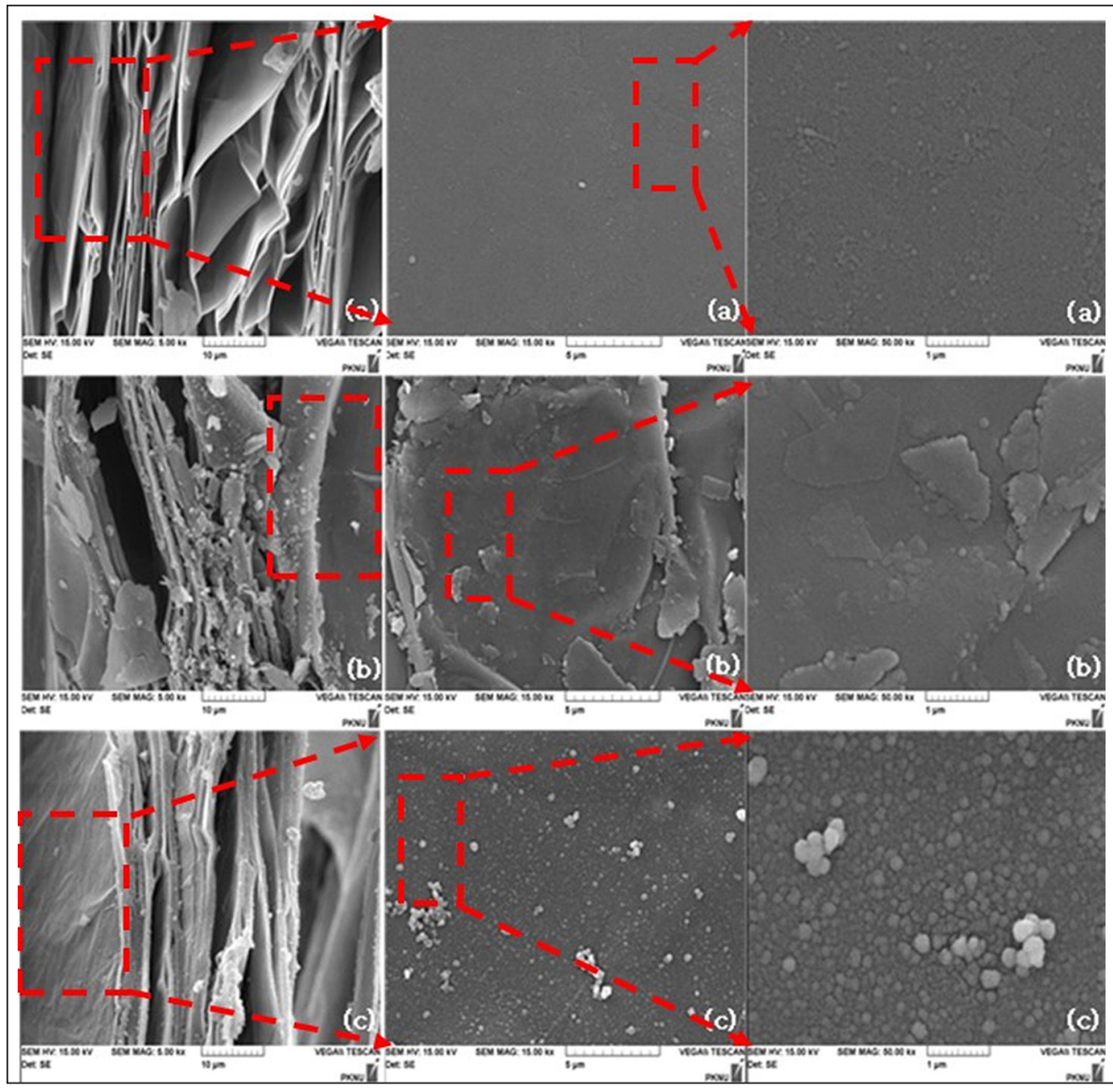

Figure 3. SEM images of (a) EV, (b) SCV, and (c) SCV after batch sorption tests 
Table 3. EDS analysis of EV, SCV and SCV after phosphorus adsorption

\begin{tabular}{|c|c|c|c|c|c|c|}
\hline \multirow[t]{2}{*}{ Elements } & \multicolumn{2}{|c|}{ EV } & \multicolumn{2}{|c|}{ SCV } & \multicolumn{2}{|c|}{ After adsorption } \\
\hline & $\begin{array}{c}\text { Mass ratio } \\
\text { (wt.\%) }\end{array}$ & $\begin{array}{c}\text { Atomic ratio } \\
\text { (at.\%) }\end{array}$ & $\begin{array}{c}\text { Mass ratio } \\
\text { (wt.\%) }\end{array}$ & $\begin{array}{c}\text { Atomic ratio } \\
\text { (at.\%) }\end{array}$ & $\begin{array}{c}\text { Mass ratio } \\
\text { (wt.\%) }\end{array}$ & $\begin{array}{c}\text { Atomic ratio } \\
\text { (at.\%) }\end{array}$ \\
\hline 0 & 48.8 & 63.3 & 56.89 & 70.1 & 52.4 & 66.32 \\
\hline $\mathrm{Na}$ & 0.85 & 0.77 & 0 & 0 & 0 & 0 \\
\hline $\mathrm{Mg}$ & 13.71 & 11.7 & 11.32 & 9.18 & 11.1 & 9.24 \\
\hline Al & 6.1 & 4.69 & 4.94 & 3.61 & 4.69 & 3.52 \\
\hline $\mathrm{Si}$ & 19.27 & 14.24 & 18.1 & 12.7 & 23.7 & 17.09 \\
\hline $\mathrm{K}$ & 5.32 & 2.82 & 3.21 & 1.62 & 3.67 & 1.9 \\
\hline $\mathrm{Ca}$ & 1.43 & 0.74 & 0 & 0 & 0 & 0 \\
\hline $\mathrm{Ti}$ & 0.79 & 0.34 & 0.46 & 0.19 & 0.81 & 0.34 \\
\hline $\mathrm{Cr}$ & 0.3 & 0.12 & 0 & 0 & 0 & 0 \\
\hline $\mathrm{Fe}$ & 3.43 & 1.27 & 2.03 & 0.72 & 2.63 & 0.95 \\
\hline$S$ & 0 & 0 & 3.06 & 1.88 & 0.99 & 0.63 \\
\hline
\end{tabular}
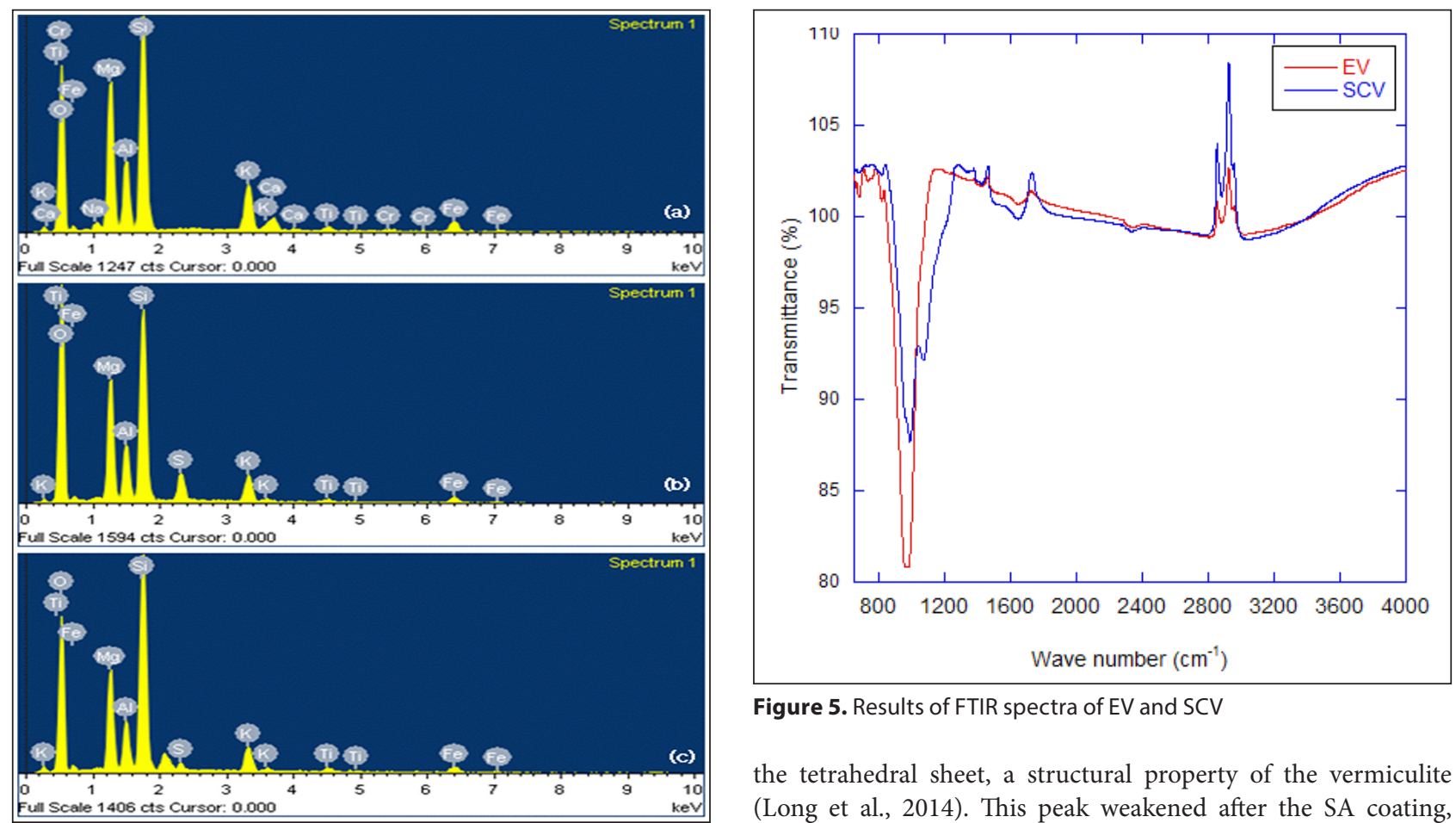

Figure 4. Results of EDS analysis of (a) EV, (b) SCV, and (c) SCV after batch sorption tests

The results of the dispersive $\mathrm{x}$-ray spectroscopy (SEM-EDS) analysis are shown in Fig. 4 and summarized in Table 3. Here the S peak (3.06\%) that could not exist in EV is observed in SCV, indicating that sulfate $\left(\mathrm{SO}_{4}{ }^{2-}\right)$ is attached to the vermiculite after coating with SA. Because sulfate coated on SCV has a lower shared charge value than phosphorus in water, it is considered that the concentration is reduced because it is easily replaced by phosphorus. In addition, the $\mathrm{Al}, \mathrm{Mg}$ and Fe peaks in the SCV are decreased more than those in EV. Like the XRF results, SEM-EDS shows that the octahedral cation was leached after the SA-coating treatment (Long et al., 2014).

\section{FTIR analysis of adsorbents}

Figure 5 shows the FTIR spectra of EV and SCV. The strongest peaks of EV and SCV are shown at $974 \mathrm{~cm}^{-1}$ and $989 \mathrm{~cm}^{-1}$, respectively, representing the stretching vibrations of the $\mathrm{Si}-\mathrm{OH}$ non-bridging oxygen atoms (Shin et al., 2004). EV peaks at $680 \mathrm{~cm}^{-1}, 735 \mathrm{~cm}^{-1}$ and $974 \mathrm{~cm}^{-1}$ are relevant to the Si-O stretching vibration between $\mathrm{Si}-\mathrm{O}-\mathrm{Si}$ in the silica layer and $\mathrm{Si}-\mathrm{OH}$ in

Figure 5. Results of FTIR spectra of EV and SCV

the tetrahedral sheet, a structural property of the vermiculite (Long et al., 2014). This peak weakened after the SA coating, possibly because the octahedral cation was diminished due to the extraction from the octahedral sheet (Long et al., 2014). The $1648 \mathrm{~cm}^{-1}$ peak is mainly due to the absorption of $\delta\left(\mathrm{H}_{2} \mathrm{O}\right)$ by a water molecule in the vermiculite, and explains why the silica layer changed from hydrophilic to hydrophobic (Long et al., 2014; Yu et al., 2010). Additionally, the attachment of sulfate in SCV is observed at the $1067 \mathrm{~cm}^{-1}$ peak (Choi et al., 2012).

\section{Batch kinetic tests}

For the comparison of EV and SCV for the removal of phosphorus, one batch test was conducted for phosphorus removal. Figure 6 shows the concentrations of phosphorus removed by the EV and SCV where $0.5 \mathrm{~g}$ of adsorbent in $40 \mathrm{~mL}$ solution and initial phosphorus concentration of $20 \mathrm{mg} \cdot \mathrm{L}^{-1}$ was used. Phosphorus concentrations were dramatically decreased within $10 \mathrm{~s}$ (more than $80 \%$ ), but the EV, unlike the SCV, removed little phosphorus. The good correspondence between the data and the equation fit indicates that phosphorus removal follows a first-order reaction. The $K_{\text {obs }}\left(\mathrm{h}^{-1}\right)$ and $K_{p}\left(\mathrm{~L} \cdot \mathrm{kg}^{-1}\right)$ of SCV were 0.377 and 684.8, respectively. On the contrary, no fitting parameters were obtained for EV. The $K_{\text {obs }}\left(\mathrm{h}^{-1}\right)$ and $K_{p}\left(\mathrm{~L} \cdot \mathrm{kg}^{-1}\right)$ for the batch kinetic tests are summarized in Table 4. 
Table 4. Instantaneous partition coefficients and first-order rate constants for phosphorus removal using various vermiculites under different test conditions

\begin{tabular}{lccccc}
\hline Reactive media & $\begin{array}{c}\text { Dose } \\
\left(\mathbf{g} \cdot \mathbf{L}^{-1}\right)\end{array}$ & $\begin{array}{c}\text { Initial phosphorus } \\
\text { concentration }\left(\mathbf{m g} \cdot \mathbf{L}^{-1}\right)\end{array}$ & $\begin{array}{c}\text { Removal rate } \\
\text { after } \mathbf{h}(\%)\end{array}$ & $\begin{array}{c}K_{\text {obs }} \\
\left(\mathbf{h}^{-1}\right)\end{array}$ & $\begin{array}{c}K_{p} \\
\left(\mathbf{L} \cdot \mathbf{k g}^{-1}\right)\end{array}$ \\
\hline EV & 12.5 & 20 & - & - & - \\
SCV & 12.5 & 20 & 99.99 & 0.377 & 684.81 \\
SCV & 1 & 40 & 9.5 & 0.00015 & 58.97 \\
SCV & 2.5 & 40 & 35 & 0.0011 & 67.90 \\
SCV & 5 & 40 & 71.75 & 0.0044 & 78.83 \\
SCV & 7.5 & 40 & 85.25 & 0.0087 & 90.17 \\
SCV & 12.5 & 40 & 99.99 & 0.0648 & 141.07 \\
SCV & 25 & 40 & 99.99 & 0.5002 & 166.61 \\
SCV & 12.5 & 10 & 99.99 & 0.549 & 730.66 \\
SCV & 12.5 & 20 & 99.99 & 0.377 & 684.81 \\
SCV & 12.5 & 30 & 99.99 & 0.208 & 370.54 \\
SCV & 12.5 & 40 & 99.99 & 0.065 & 141.07 \\
SCV & 12.5 & 50 & 99.01 & 0.032 & 112.72 \\
\hline
\end{tabular}

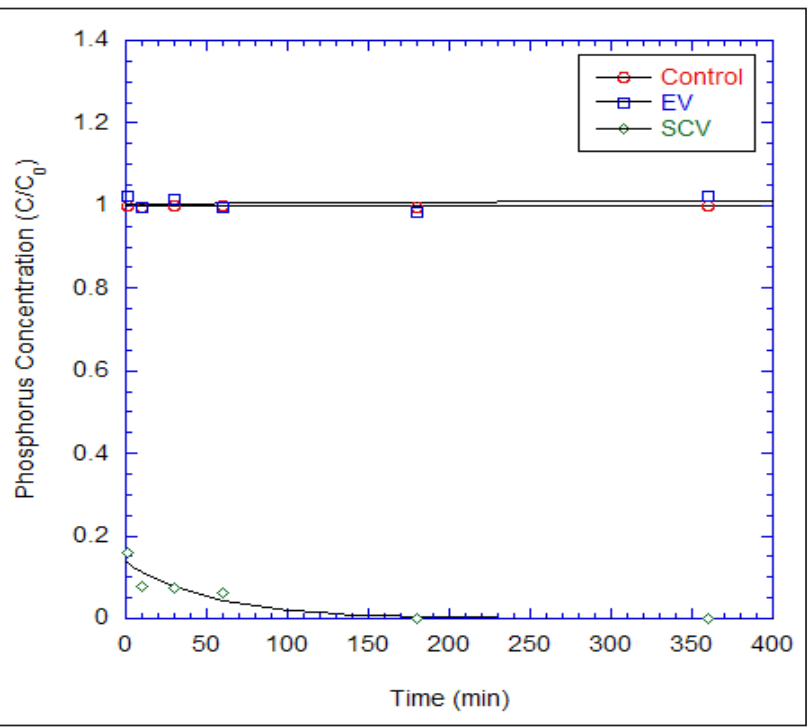

Figure 6. Adsorption of phosphorus by EV and SCV according to the time (adsorbent concentration: $25 \mathrm{~g} \cdot \mathrm{L}^{-1}$; phosphorus concentration: $20 \mathrm{mg}^{\mathrm{L}} \mathrm{L}^{-1}$ )

On the basis of the above results, SCV was selected as an adsorbent for the removal of phosphorus, and additional batch kinetic tests were conducted for various ratios of an adsorbent-phosphorus solution. Phosphorus removal patterns for different ratios of SCV and phosphorus solution of $40 \mathrm{~mL}$ with an initial phosphorus concentration of $40 \mathrm{mg} \cdot \mathrm{L}^{-1}$ are shown in Fig. 7 and Table 4. The removal rates for $1,2.5,5$ and $7.5 \mathrm{~g} \cdot \mathrm{L}^{-1}$ of SCVs at a time of $360 \mathrm{~min}$ were $9.5 \%, 35 \%, 71.75 \%$ and $85.25 \%$, respectively. As no phosphorus was detected after $60 \mathrm{~min}$ at $12.5 \mathrm{~g} \cdot \mathrm{L}^{-1}$ and $25 \mathrm{~g} \cdot \mathrm{L}^{-1}$ of SCVs, the removal rates were almost $99.99 \%$. Based on these results, we can confirm that higher SCV dosage results in higher removal rates. The fitting parameters obtained by applying Eq. 4 to the phosphorus removal data are shown in Fig. $7 \mathrm{~b}$. The removal rate constant $K_{\text {obs }}\left(\mathrm{h}^{-1}\right)$ shows a rapidly increasing pattern as the amount of SCV increases: 0.00015 at $1.0 \mathrm{~g} \cdot \mathrm{L}^{-1}$ to 0.5002 at $25 \mathrm{~g} \cdot \mathrm{L}^{-1}$. Furthermore, the instantaneous partition coefficient $K_{p}\left(\mathrm{~L}^{\cdot \mathrm{kg}^{-1}}\right)$ was quickly increased, similarly to the removal rate constant, from 58.97 at $1 \mathrm{~g} \cdot \mathrm{L}^{-1}$ to 166.61 at $25 \mathrm{~g} \cdot \mathrm{L}^{-1}$.

Figure 8 shows the concentration changes of the phosphorus solutions with time, where the initial concentrations are 10, 20,

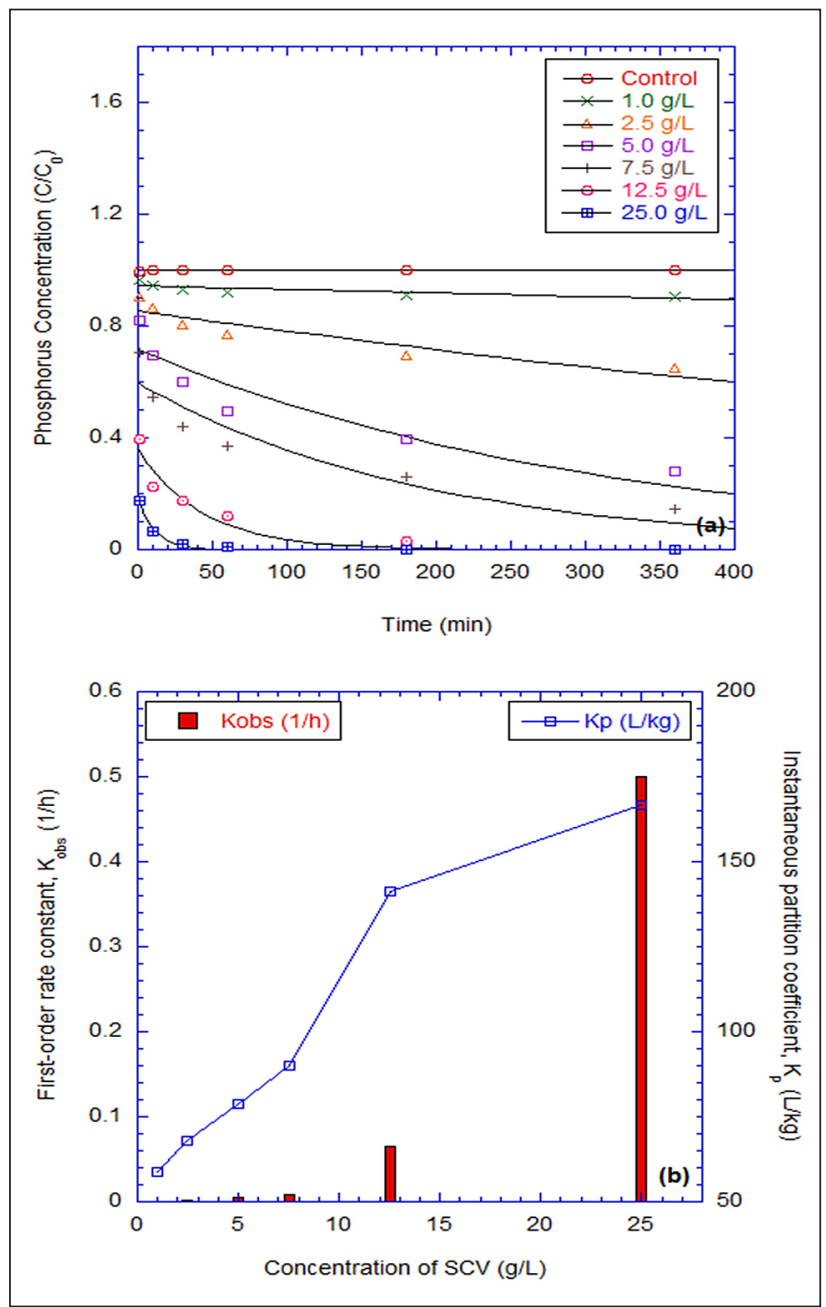

Figure 7. Adsorption behaviour of phosphorus at (a) different dosage of SCV and (b) fitting parameters obtained by Eq. 4

30, 40 and $50 \mathrm{mg} \cdot \mathrm{L}^{-1}$, and $0.5 \mathrm{~g}$ of SCV is added. Test conditions are summarized in Table 4 . The phosphorus ions were effectively removed, with removal rates of almost $99 \%$. With these results, the first-order rate constant and instantaneous partition coefficient were obtained using Eq. 4 and the results are summarized in Table 4. 
Table 5. The pseudo first-order kinetic model and the pseudo second-order kinetic model parameter of phosphorus adsorption with different initial concentrations, using SCV

\begin{tabular}{|c|c|c|c|c|c|c|c|c|c|}
\hline \multirow{2}{*}{$\begin{array}{l}\text { Initial conc. } \\
\left(\mathrm{mg} \cdot \mathrm{L}^{-1}\right)\end{array}$} & \multirow[t]{2}{*}{$q_{e . e x p}\left(m g \cdot g^{-1}\right)$} & \multicolumn{4}{|c|}{ Pseudo first-order kinetic model } & \multicolumn{4}{|c|}{ Pseudo second-order kinetic model } \\
\hline & & $\begin{array}{c}q_{e . c a l} \\
\left(\mathrm{mg} \cdot \mathrm{g}^{-1}\right)\end{array}$ & $\begin{array}{c}k_{1} \\
\left(\min ^{-1}\right)\end{array}$ & $R^{2}$ & $\begin{array}{l}\Delta q \\
(\%)\end{array}$ & $\begin{array}{c}q_{e . c a l} \\
\left(\mathrm{mg} \cdot \mathrm{g}^{-1}\right)\end{array}$ & $\begin{array}{c}k_{2} \\
\left(\mathrm{~g} \cdot \mathrm{mg}^{-1} \cdot \mathrm{min}^{-1}\right)\end{array}$ & $R^{2}$ & $\Delta q(\%)$ \\
\hline 10 & 0.8 & 0.044 & 0.0065 & 0.8049 & 55.51 & 0.801 & 3.064 & 1.0000 & 0.00072 \\
\hline 20 & 1.6 & 0.114 & 0.0068 & 0.9288 & 54.13 & 1.604 & 0.833 & 1.0000 & 0.00085 \\
\hline 30 & 2.4 & 0.292 & 0.0075 & 0.9298 & 45.78 & 2.409 & 0.332 & 1.0000 & 0.0025 \\
\hline 40 & 3.2 & 1.061 & 0.0061 & 0.9667 & 22.73 & 3.227 & 0.063 & 0.9995 & 0.0173 \\
\hline 50 & 3.96 & 1.568 & 0.0055 & 0.9956 & 15.17 & 4.021 & 0.031 & 0.9988 & 0.0136 \\
\hline
\end{tabular}

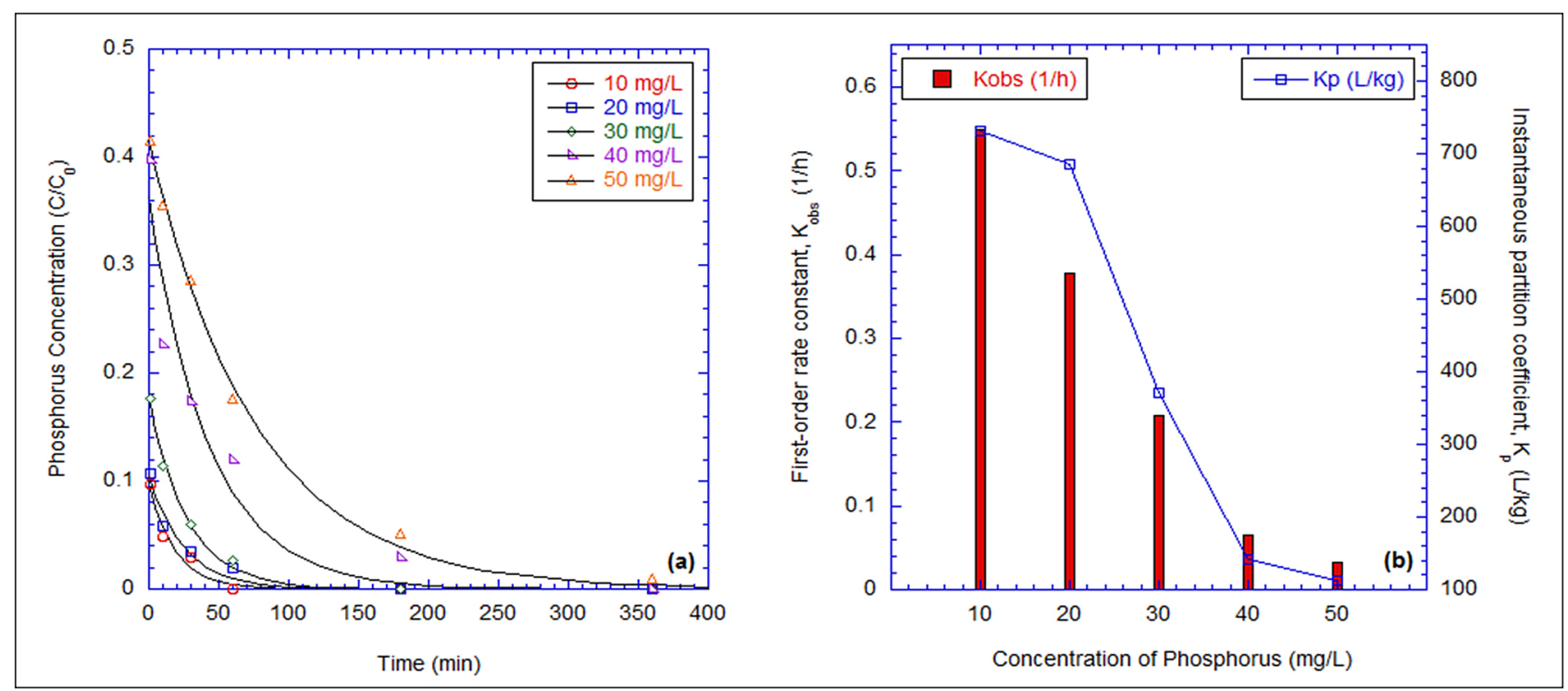

Figure 8. Adsorption behaviour of phosphorus tested with $12.5 \mathrm{~g} \cdot \mathrm{L}^{-1} \mathrm{SCV}$ at (a) different initial phosphorus concentrations and (b) fitting parameters obtained by Eq. 4

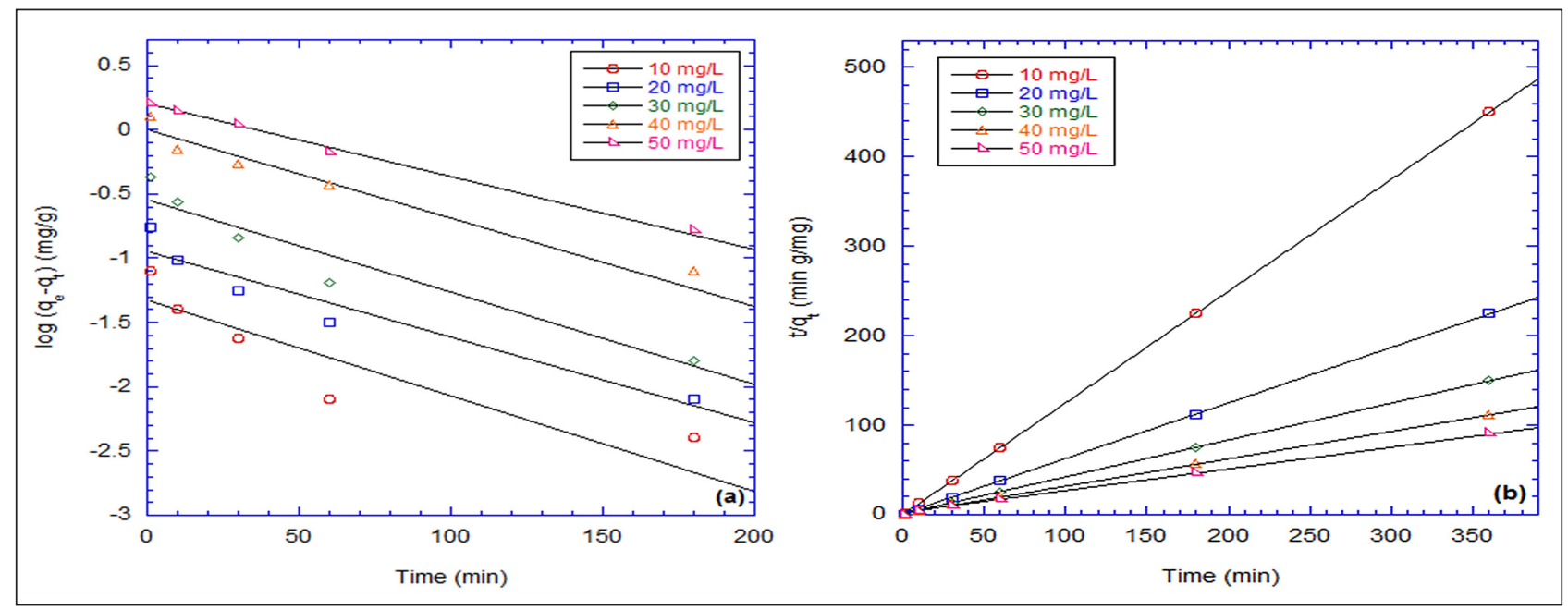

Figure 9. Results of (a) pseudo first-order model fits and (b) pseudo second-order model fitting for batch kinetic tests for different initial

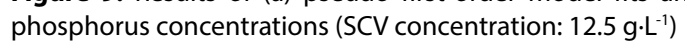

As shown in Fig. 8b, the highest concentration of phosphorus resulted in highest $K_{\mathrm{obs}}$ but lowest $K_{p}$. By increasing the initial concentration, the removal constants, $K_{\mathrm{obs}}\left(\mathrm{h}^{-1}\right)$, were decreased to $0.549,0.377,0.208,0.065$ and 0.032 . When the initial concentration was increased, the instantaneous partition coefficients decreased to $730.7,684.8,370.5,141.1$ and $112.7 \mathrm{~L} \cdot \mathrm{kg}^{-1}$.

The parameters of pseudo first-order and second-order model are summarized in Table 5 and model fits are shown in Fig. 9. It is clear that the process of phosphate adsorption onto SCV is well described by the pseudo second-order model because of the high correlation coefficient. The correlation coefficients for the fitting of the pseudo second-order model range between 0.9988 and 1.0000. The calculated amount of phosphate adsorbed on SCV at equilibrium $\left(q_{e, \text { cal }}\right)$ was quickly increased from $0.80 \mathrm{mg} \cdot \mathrm{g}^{-1}$ at $10 \mathrm{mg} \cdot \mathrm{L}^{-1}$ to $4.02 \mathrm{mg} \cdot \mathrm{g}^{-1}$ at $50 \mathrm{mg} \cdot \mathrm{L}^{-1}$. This phenomenon was due to both increased contact time between adsorbent and adsorbate, and an increased concentration difference between the surface of the SCV and adsorbate in solution. On the contrary, $k_{2}\left(\mathrm{~g} \cdot \mathrm{mg}^{-1} \cdot \mathrm{min}^{-1}\right)$ was decreased from 3.064 at $10 \mathrm{mg} \cdot \mathrm{L}^{-1}$ to 0.031 at $50 \mathrm{mg} \cdot \mathrm{L}^{-1}$. 
Table 6. Adsorption parameters of linear, Freundlich, and Langmuir models for phosphorus adsorption on the SCV

\begin{tabular}{|c|c|c|c|c|c|c|c|c|}
\hline & \multicolumn{2}{|c|}{ Linear model } & \multicolumn{3}{|c|}{ Freundlich model } & \multicolumn{3}{|c|}{ Langmuir model } \\
\hline & $K_{p}\left(\mathrm{~L} \cdot \mathrm{g}^{-1}\right)$ & $R^{2}$ & $K_{f}\left(\mathrm{~L} \cdot \mathrm{g}^{-1}\right)$ & $1 / n$ & $R^{2}$ & $Q_{\max }\left(m g \cdot g^{-1}\right)$ & $K_{\mathrm{l}}\left(\mathrm{L} \cdot \mathrm{mg}^{-1}\right)$ & $R^{2}$ \\
\hline SCV & 0.6544 & 0.6845 & 4.5974 & 0.354 & 0.7943 & 8.921 & 1.403 & 0.9919 \\
\hline
\end{tabular}

Table 7. Comparison of the maximum adsorption capacity of different adsorbents for phosphorus in aqueous solutions

\begin{tabular}{|c|c|c|}
\hline Adsorbent & Removal capacity $\left(\mathrm{mg} \cdot \mathrm{g}^{-1}\right)$ & Author \\
\hline Kanuma mud & 1.14 & Yang et al. (2013) \\
\hline Goethite & 2.78 & Zhong et al. (2007) \\
\hline Lagoon fly ash & 3.082 & Cheung and Venkitachalam (2000) \\
\hline Wood fibre & 4.3 & Eberhardt et al. (2006) \\
\hline Alumina-coated carboxylated & 5.23 & Saha et al. (2008) \\
\hline ACF-La & 5.85 & Zhang et al. (2011) \\
\hline Lanthanum-doped vesuvianite & 6.7 & Li et al. (2009) \\
\hline Iron oxide tailings & 8.21 & Zeng et al. (2004) \\
\hline Sulfate-coated vermiculite & 8.921 & In this study \\
\hline Zirconium ferrite & 13 & Biswas et al. (2008) \\
\hline Scallop shell & 23 & Yeom and Jung (2008) \\
\hline Activated red mud & 23.23 & Pradhan et al. (1998) \\
\hline Sawdust & 28.79 & Unnithan et al. (2002) \\
\hline Aluminium oxide & 34.57 & Peleka and Deliyanni (2009) \\
\hline Hydrotalcite & 60.00 & Peleka and Deliyanni (2009) \\
\hline Silica sulfate & 46.32 & Jutidamrongphan et al. (2012) \\
\hline Hydrotalcite & 22.22 & Choi et al. (2012) \\
\hline Activated alumina & 49.67 & Choi et al. (2012) \\
\hline Zeolite & 111.49 & Choi et al. (2012) \\
\hline nZVI & 245.65 & Wen et al. (2014) \\
\hline
\end{tabular}

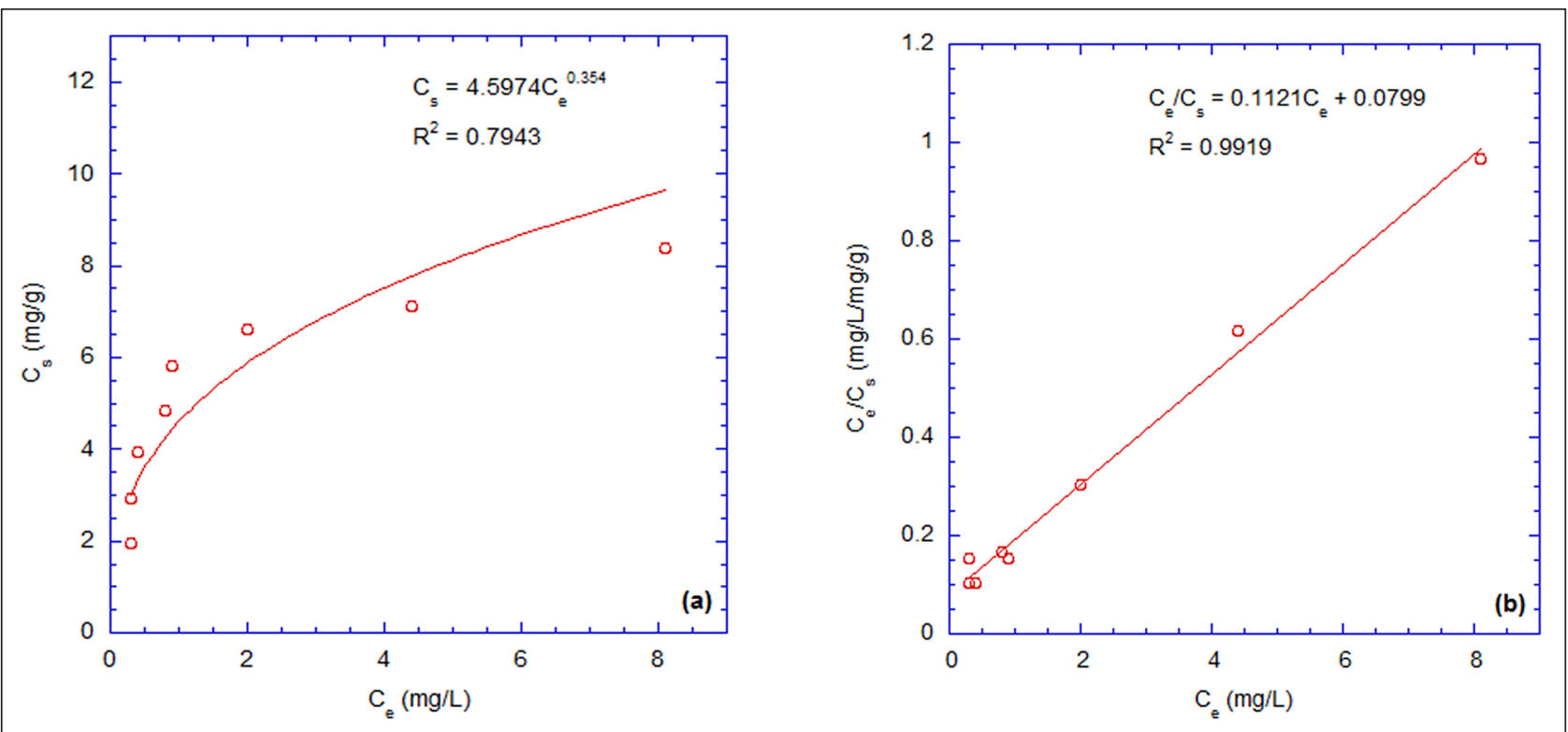

Figure 10. Adsorption isotherms for phosphorus ions on SCV and model fit with (a) Freundlich and (b) Langmuir models

\section{Batch adsorption tests}

Linear, Freundlich, and Langmuir models were fitted to the isotherm data using least-squares approximations. Results of batch adsorption tests are shown in Fig. 10 and fitting parameters are summarized in Table 6 . As the coefficients of determination of the linear and Freundlich models are $R^{2}=0.685$ and $R^{2}=0.794$, respectively, the Langmuir model is more appropriate as it has the highest coefficient of determination $\left(R^{2}=0.9919\right)$. The adsorption constant $\left(K_{1}\right)$ for the Langmuir model is $1.403 \mathrm{~L} \cdot \mathrm{mg}^{-1}$ with a $Q_{\max }$ of $8.921 \mathrm{mg} \cdot \mathrm{g}^{-1}$. $Q_{\max }$ for phosphorus using various adsorbents are summarized in Table 7. Kanuma mud, geothite, lagoon fly ash, wood fibre, alumina-coated carboxylate, ACF-La, and lanthanum-doped vesuvianite showed lower $Q_{\max }$ than that of this study (Saha et al., 2008; Yang et al., 2013; Zhang et al., 2011; Cheung and Venkitachalam, 2000; Zhong et al., 2007; Eberhardt et al., 2006; Li et al., 2009). Other adsorbents showed extremely high $Q_{\max }$ for phosphorus, of greater than $100 \mathrm{mg} \cdot \mathrm{g}^{-1}$ (Choi et al., 2012; Wen et al., 2014). 
Table 8. Instantaneous partition coefficients, first-order rate constants and removal rates of SCV under various conditions

\begin{tabular}{|c|c|c|c|c|c|c|}
\hline Conditions & $\begin{array}{l}\text { Amount of } \\
\operatorname{SCV}(g)\end{array}$ & $\begin{array}{c}\text { Final sulfate } \\
\text { concentration }\left(\mathrm{mg} \cdot \mathrm{L}^{-1}\right)\end{array}$ & $\begin{array}{l}\text { Initial P concentration } \\
\left(\mathrm{mg} \cdot \mathrm{L}^{-1}\right)\end{array}$ & $\begin{array}{l}\text { \% } \mathrm{P} \text { removal } \\
\text { after reaction }\end{array}$ & $\begin{array}{l}K_{\text {obs }} \\
\left(h^{-1}\right)\end{array}$ & $\begin{array}{c}K_{p} \\
\left(\mathrm{~L} \cdot \mathrm{kg}^{-1}\right)\end{array}$ \\
\hline Phase 1 (P1) & 1.0 & 2400 & 40 & 99.99 & 0.361 & 113.2 \\
\hline Phase 2 (P2) & 1.0 & 240 & 40 & 87.5 & 0.0069 & 21.8 \\
\hline Phase 3 (P3) & 1.0 & 40 & 40 & 66.75 & 0.00087 & 17.5 \\
\hline
\end{tabular}

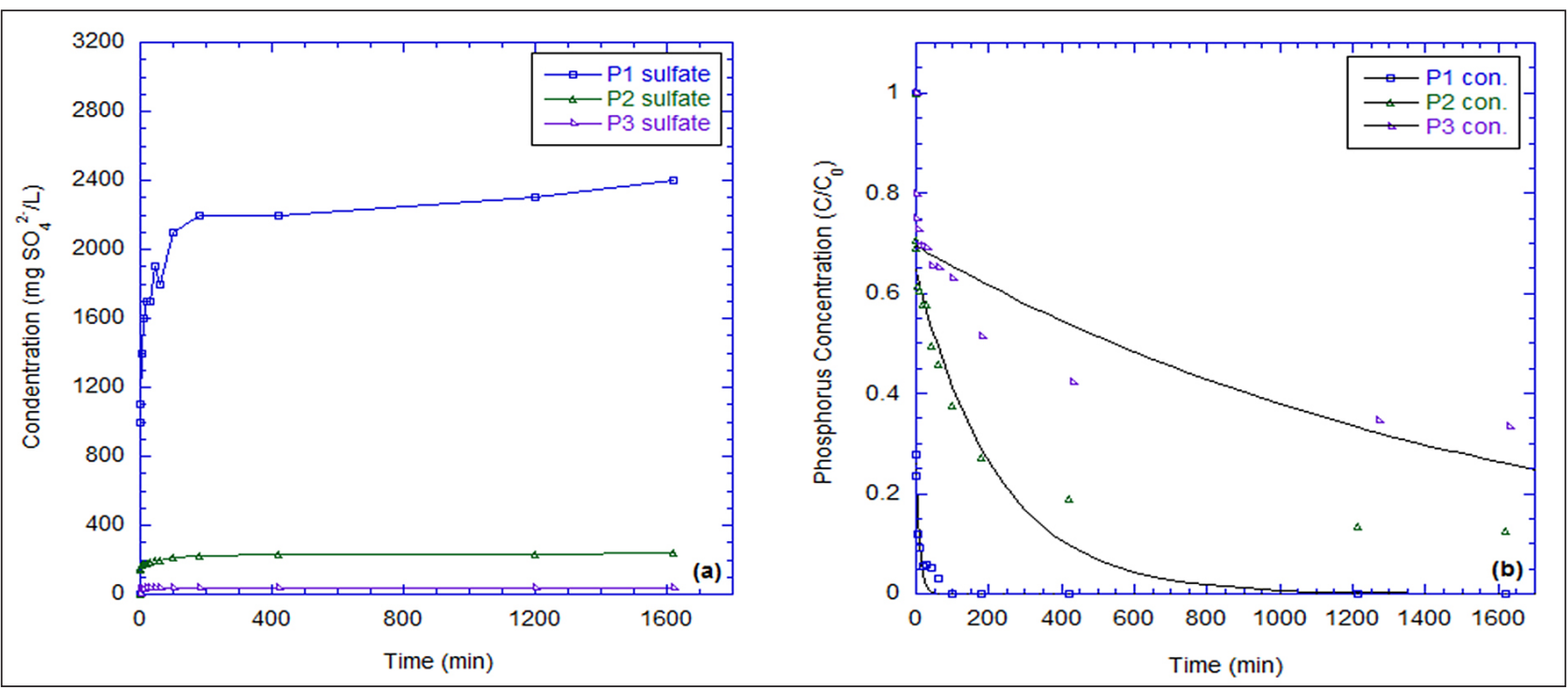

Figure 11. Results of sequential leaching tests for $25 \mathrm{~g} \cdot \mathrm{L}^{-1} \mathrm{SCV}$ with an initial phosphorus concentration of $40 \mathrm{mg} \cdot \mathrm{L}^{-1}:(\mathrm{a})$ leached concentrations of sulfate after first, second, and third

\section{Leaching of sulfate from SCV and effects on phosphorus removal}

Sequential batch leaching tests were conducted to determine the amount of sulfate leached from SCV and its effects on phosphate removal. Test results are shown in Fig. 11 and summarized in Table 8.

In the first test (Phase 1, P1), the concentration of sulfate was dramatically increased from 0 to $1800 \mathrm{mg} \cdot \mathrm{L}^{-1}$ within $60 \mathrm{~min}$ and slowly increased to $2400 \mathrm{mg} \cdot \mathrm{L}^{-1}$. The leached concentrations of sulfate, however, were decreased to $240 \mathrm{mg} \cdot \mathrm{L}^{-1}$ in the second test (Phase 2, P2) and $40 \mathrm{mg} \cdot \mathrm{L}^{-1}$ in the third test (Phase 3, P3).

During the sequential batch leaching tests, phosphate concentrations were measured and analysed using Eq. 4 to obtain the kinetic parameters for phosphate removal. The removal rates of phosphate at a time of 1600 min were $99.99 \%$ (P1), 87.5\% (P2), and $66.75 \%(\mathrm{P} 3)$. The removal rate constant $\left(K_{\mathrm{obs}}\right)$ was rapidly decreased from $0.361 \mathrm{~h}^{-1}(\mathrm{P} 1)$ to $0.00087 \mathrm{~h}^{-1}$ (P3). Similar results were obtained for the instantaneous partition coefficient $\left(K_{p}\right)$. The

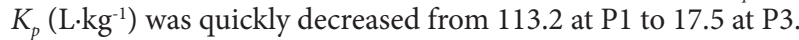

In the first test, concentration of sulfate was $2400 \mathrm{mg} \cdot \mathrm{L}^{-1}$, and in the second sulfate was only $240 \mathrm{mg} \cdot \mathrm{L}^{-1}$. At the same time, phosphate removal efficiency decreased from 99.9 to $87.5 \%$. A larger decrease in phosphate removal efficiency can be expected with decreased sulfate concentration. In the third experiment, as the sulfate concentration decreased from $240 \mathrm{mg} \cdot \mathrm{L}^{-1}$ to $40 \mathrm{mg} \cdot \mathrm{L}^{-1}$, the phosphorus removal efficiency decreased from $87.5 \%$ to $66.75 \%$. The change in sulfate concentration is much larger than the change in phosphorus removal efficiency.

Therefore, the removal mechanism for phosphate was assumed to be the anion exchange with sulfate coated on the SCV.

\section{Column tests}

Results for the column tests are shown in Fig. 12 and Table 9. The effect of influent phosphate concentration on the breakthrough curve was examined in the range of $10-50 \mathrm{mg} \cdot \mathrm{L}^{-1}$ at a flow rate of $5 \mathrm{~mL} \cdot \mathrm{min}^{-1}$. Increasing influent phosphate concentration resulted in decreasing the breakthrough time (Fig. 12a). A decrease in phosphate concentration resulted in a later breakthrough curve, and the treated volume of phosphate solution was greatest at the lowest influent concentration. In addition, the bed adsorption capacity $\left(q_{e}, \mathrm{mg} \cdot \mathrm{g}^{-1}\right)$ increased from 7.5 to 19.5 at influent phosphate concentration of 10 and $50 \mathrm{mg} \cdot \mathrm{L}^{-1}$, respectively. This could be explained by the high influent phosphate concentration, which provided a greater driving force for the transfer process to overcome mass transfer resistance (Na and Park, 2011; Woumfo et al., 2015); an increased ratio of phosphate to SCV amount also resulted in higher $q_{e}$.

Table 9. Column data parameter obtained at different influent phosphate concentration and flow rates

\begin{tabular}{|c|c|c|c|c|c|c|}
\hline Adsorbent & Exp. parameters & $\begin{array}{c}C_{0} \\
\left(\mathrm{mg} \cdot \mathrm{L}^{-1}\right)\end{array}$ & $\begin{array}{c}Q \\
\left(\mathrm{~mL} \cdot \mathrm{min}^{-1}\right)\end{array}$ & $\begin{array}{c}H \\
(\mathrm{~cm})\end{array}$ & $\begin{array}{l}\text { EBCT } \\
\text { (min) }\end{array}$ & $\begin{array}{c}q_{e} \\
\left(\mathrm{mg} \cdot \mathrm{g}^{-1}\right)\end{array}$ \\
\hline \multirow[t]{6}{*}{ SCV } & Initial con. $\left(C_{0}\right)$ & 10 & 5 & 30 & 142.54 & 7.47 \\
\hline & & 25 & 5 & 30 & 142.54 & 14.69 \\
\hline & & 50 & 5 & 30 & 142.54 & 19.53 \\
\hline & Flow rate & 25 & 3 & 30 & 237.58 & 16.63 \\
\hline & & 25 & 5 & 30 & 142.54 & 14.69 \\
\hline & & 25 & 7 & 30 & 101.82 & 13.14 \\
\hline
\end{tabular}




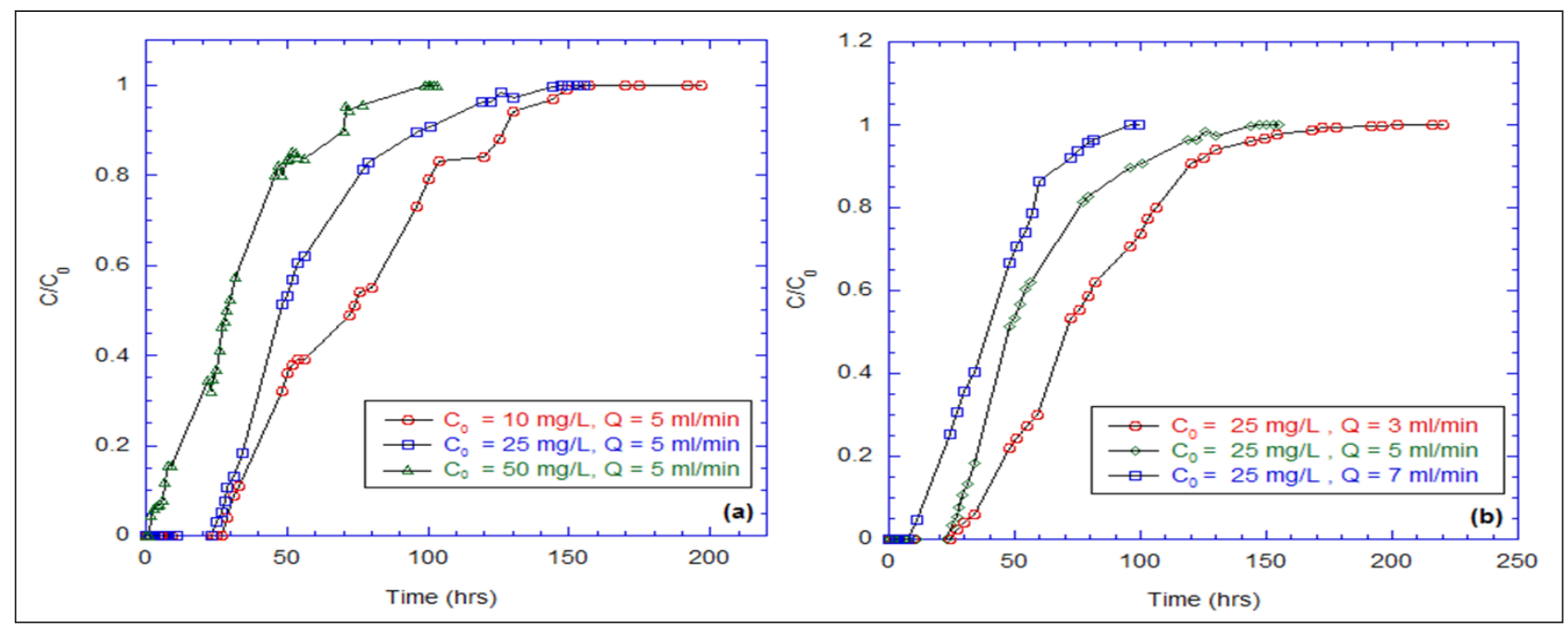

Figure 12. Results of column sorption tests for $\mathrm{SCV}$ at (a) different initial phosphorus concentrations at a fixed flow rate $\left(5 \mathrm{~mL} \cdot \mathrm{min}^{-1}\right)$, and (b) different flow rates at a fixed initial phosphorus concentration of $25 \mathrm{mg} \cdot \mathrm{L}^{-1}$

The effect of flow rate on the adsorption of phosphate was tested in the ranges of $3-7 \mathrm{~mL} \cdot \mathrm{min}^{-1}$ at an influent phosphate concentration of $25 \mathrm{mg} \cdot \mathrm{L}^{-1}$. Breakthrough occurred faster at an increased flow rate. As the flow rate increased from 3 to $7 \mathrm{~mL} \cdot \mathrm{min}^{-1}$, the EBCT decreased from 237.6 to $101.8 \mathrm{~min}$ (Table 9), and $q_{e}\left(\mathrm{mg} \cdot \mathrm{g}^{-1}\right.$ ) decreased from 16.6 to 13.1 (Table 9). The breakthrough curve became steeper as the flow rate increased because the phosphate did not have enough contact time with SCV at a high flow rate. This low contact time resulted in a lower phosphate removal efficiency.

Sun et al. (2014) reported that the $q_{e}$ had a range of 11.6$21.1 \mathrm{mg} \cdot \mathrm{g}^{-1}$ in a column test using oxidized $\mathrm{Mg}_{3}-\mathrm{Fe}$, and Woumfo et al. (2015) suggested a range of $2.8-5.9 \mathrm{mg} \cdot \mathrm{g}^{-1}$ using an andosolbagasse mixture. In the case of silica sulfate, Jutidamrongphan et al. (2012) reported a $q_{e}$ of $37.6 \mathrm{mg} \cdot \mathrm{g}^{-1}$, higher than the $q_{e}$ of the present study.

\section{CONCLUSIONS}

The following conclusions were obtained after we evaluated the applicability of EV and SCV as adsorbents, and their adsorption capacity for removal of phosphorus from an aqueous solution. In general, EV was not effective for phosphorus removal but SCV showed good removal capacity for phosphorus.

Results of serial batch kinetic tests with SCV showed rapid phosphorus removal rates that could be successfully modelled by a first-order model with instantaneous adsorption. The rate constants and instantaneous partition coefficients increased with SCV/solution ratio. The removal rate constant $K_{\text {obs }}\left(\mathrm{h}^{-1}\right)$ shows a rapidly increasing pattern as the amount of SCV increases: 0.00015 at $1.0 \mathrm{~g} \cdot \mathrm{L}^{-1}$ to 0.5002 at $25 \mathrm{~g} \cdot \mathrm{L}^{-1}$. Furthermore, the instantaneous partition coefficient $K_{p}\left(\mathrm{~L}^{\mathrm{kg}} \mathrm{kg}^{-1}\right)$ was quickly increased, similarly to the removal rate constant, from 58.97 at $1 \mathrm{~g} \cdot \mathrm{L}^{-1}$ to 166.61 at $25 \mathrm{~g} \cdot \mathrm{L}^{-1}$.

For the tests with different initial phosphorus concentrations, the removal rate constants $\left(K_{\text {obs }}, h^{-1}\right)$ decreased with initial phosphorus concentration but the instantaneous partition coefficients showed similar values regardless of initial phosphorus concentration.

From pseudo first-order and pseudo second-order model fits on the batch kinetic data, we found that the process of phosphate adsorption onto SCV was well described by the pseudo secondorder model because of the high determination coefficient.

From the batch adsorption tests, we found that the Langmuir model was the most appropriate. The adsorption constant $\left(K_{1}\right)$ for the Langmuir model was $1.403 \mathrm{~L} \cdot \mathrm{mg}^{-1}$ and $Q_{\max }$ of $8.921 \mathrm{mg} \cdot \mathrm{g}^{-1}$.
The bed adsorption capacity $\left(q_{e}\right)$ obtained from the column tests at a flow rate of $5 \mathrm{~mL} \cdot \mathrm{min}^{-1}$ were $7.47,14.69$ and $19.53 \mathrm{mg} \cdot \mathrm{g}^{-1}$ at initial concentrations of 10,25 and $50 \mathrm{mg} \cdot \mathrm{L}^{-1}$, respectively.

The adsorption capacity values from the batch adsorption $\left(Q_{\max }\right)$ and the column tests $\left(q_{e}\right)$ were significantly different. We assume that a better adsorption environment was provided by the column tests rather than the batch adsorption tests.

The SCV used in this study showed excellent adsorption capacity compared to various sorbents evaluated in other studies. In particular, the SCV showed rapid phosphorus removal rates via instantaneous adsorption reaction and also had floating ability. In addition, the floating ability of SCV could give additional potential for the separation of SCV and water.

\section{ACKNOWLEDGEMENTS}

This work was funded by the National Research Foundation of Korea under Grant C-D-2018-0411.

\section{REFERENCES}

AKAY G, KESKINLER B, CAKICI A and DANIS U (1998) Phosphate removal from water by red mud using crossflow microfiltration. Water Res. 32 (3) 717-726. https://doi.org/10.1016/S0043-1354(97)00236-4

AWUAL M and JYO A (2011) Assessing of phosphorus removal by polymeric anion exchangers. Desalination. 281 (2) 111-117. https:// doi.org/10.1016/j.desal.2011.07.047

BISWAS B, INOUE K, GHIMIRE K, OHTA S, HARADA H, OHTO K and KAWAKITA $H$ (2007) The adsorption of phosphate from an aquatic environment using metal-loaded orange waste. J. Colloid Interf. Sci. 312 (2) 214-223. https://doi.org/10.1016/j.jcis.2007.03.072

BISWAS B, INOUE K, GHIMIRE K, HARADA H, OHTO $\mathrm{K}$ and KAWAKITA H (2008) Removal and recovery of phosphorus from water by means of adsorption onto orange waste gel loaded with zirconium. J. Bioresour. Technol. 99 (18) 8685-8690. https://doi.org/ 10.1016/j.biortech.2008.04.015

BOWDEN L, JARVIS A, YOUNGER P and JOHNSON K (2009) Phosphorus removal from waste waters using basic oxygen steel slag. Environ. Sci. Technol. 43 (7) 2476-2481. https://doi.org/10.1021/es801626d

CABRITA M, SILVA A, OLIVEIRA P, ANGÉLICO M and NOGUEIRA M (2015) Assessing eutrophication in the Portuguese continental Exclusive Economic Zone within the European Marine Strategy Framework Directive. Ecol. Indicators. 58 (2) 286-299. https://doi. org/10.1016/j.ecolind.2015.05.044

CHEN L, WU P, CHEN M, LAI X, AHMED Z, ZHU N, DANG Z, BI $Y$ and LIU T (2018) Preparation and characterization of the ecofriendly chitosan/vermiculite biocomposite with excellent removal capacity for cadmium and lead. Appl. Clay Sci. 159 (1) 74-82. https:// doi.org/10.1016/j.clay.2017.12.050 
CHEUNG K and VENKITACHALAM T (2000) Improving phosphate removal of sand infiltration system using alkaline fly ash. Chemosphere. 41 (1) 243-249. https://doi.org/10.1016/S0045-6535 (99)00417-8

CHOI J, LEE S, LEE S, KIM E, PARK K, KIM D and HONG S (2012) Comparison of surface-modified adsorbents for phosphate removal in water. Water Air Soil Pollut. 223 (6) 2881-2890. https://doi. org/10.1007/s11270-011-1072-6

CODD G, MORRISON L and METCALF J (2005) Cyanobacterial toxins: risk management for health protection. Toxicol. Appl. Pharmacol. 203 (3) 264-272. https://doi.org/10.1016/j.taap.2004.02.016

DE-BASHAN L and BASHAN Y (2004) Recent advances in removing phosphorus from wastewater and its future use as fertilizer (19972003). Water Res. 38 (19) 4222-4246. https://doi.org/10.1016/j.wat res.2004.07.014

DEL CASTILLO H, GIL A and GRANGE P (1997) Preparation and characterization of sulfated titanium-modified pillared montmorillonite. Catal. Lett. 43 (1/2) 133-137. https://doi.org/10.1023/A:1018945329164

DITTMANN E and WIEGAND C (2006) Cyanobacterial toxins occurrence, biosynthesis and impact on human affairs. Mol. Nutr. Food Res. 50 (1) 7-17. https://doi.org/10.1002/mnfr.200500162

EBERHARDT T, MIN S and HAN J (2006) Phosphate removal by refined aspen wood fiber treated with carboxymethyl cellulose and ferrous chloride. Bioresour. Technol. 97 (18) 2371-2376. https://doi org/10.1016/j.biortech.2005.10.040

ESTRADA V, MAGGIO J and DIAZ M (2011) Water sustainability: A systems engineering approach to restoration of eutrophic Lakes Comp. Chem. Eng. 35 (8) 1598-1613. https://doi.org/10.1016/j. compchemeng.2011.03.003

GUAN Q, HU X, WU D, SHANG X, YE C and KONG H (2009) Phosphate removal in marine electrolytes by zeolite synthesized from coal fly ash. Fuel. 88 (9) 1643-1649. https://doi.org/10.1016/j. fuel.2009.02.031

HUANG W, YU X, TANG J, ZHU Y, ZHANG Y and LI D (2015) Enhanced adsorption of phosphate by flower-like mesoporous silica spheres loaded with lanthanum. Micropor. Mesopor. Mater. 217 (2) 225-232. https://doi.org/10.1016/j.micromeso.2015.06.031

JUNG O, CHOI H and CHEONG K (2000) Phosphorus removal from synthetic wastewater by waste oyster shells. J. Environ. Health Sci. 26 (1) 43-49 (in Korean).

JUTIDAMRONGPHAN W, PARK K, DOCKKO S, CHOI J and LEE $S$ (2012) High removal of phosphate from wastewater using silica sulfate. Environ. Chem. Lett. 10 (1) 21-28. https://doi.org/10.1007/ s10311-011-0323-5

KARACA S, GÜRSES A, EJDER M and ACIKYILDIZ M (2004) Kinetic modeling of liquid-phase adsorption of phosphate on dolomite. J. Colloid Interf. Sci. 277 (2) 257-263. https://doi.org/10.1016/j.jcis. 2004.04.042

KARTASHEVSKY M, SEMIAT R and DOSORETZ C (2015) Phosphate adsorption on granular ferric hydroxide to increase product water recovery in reverse osmosis-desalination of secondary effluents. Desalination. 364 (1) 53-61. https://doi.org/10.1016/j.desal.2015.02.038

KIM J, LIM C, KIM K, KIM D, LEE S and KIM J (2008) Application of adsorption characteristic of ferrous iron waste to phosphate removal from municipal wastewater. J. Kor. Soc. Environ. Agric. 27 (2) 231 238 (in Korean). https://doi.org/10.5338/KJEA.2008.27.3.231

KIM S and LEE T (2014) A study for the removal of phosphorous using coated exfoliated vermiculite. J. Kor. Geo-Environ. Soc. 15 (1) 5-13 (in Korean). https://doi.org/10.14481/jkges.2014.15.12.5

KOPPENSTEINER B (1998) The degradation of the herbicides alachlor and metolachlor by iron metal in water and soil systems. MSc dissertation, University of Wisconsin Madison. 83 pp.

KUMAR P, SUDHA S, CHAND S and SRIVASTAVA V (2010) Phosphate removal from aqueous solution using coir-pith activated carbon. Sep. Sci. Technol. 45 (10) 1463-1470. https://doi.org/10.1080 /01496395.2010.485604

LAPOINTE B, HERREN L, DEBORTOLI D and VOGEL M (2015) Evidence of sewage-driven eutrophication and harmful algal blooms in Florida's Indian River Lagoon. Harmful Algae. 43 (1) 82-102. https://doi.org/10.1016/j.hal.2015.01.004

LEE Y and YIM S (2011) Adsorption removal of phosphate from aqueous solution by olivine. J. Kor. Soc. Water Qual. 27 (4) 516-522. (In Korean).
LI H, RU J, YIN W, LIU X, WANG J and ZHANG W (2009) Removal of phosphate from polluted water by lanthanum doped vesuvianite. J. Hazardous Mater. 168 (1) 326-330. https://doi.org/10.1016/j.jhaz mat.2009.02.025

LIU C, WU P, ZHU Y and TRAN L (2016) Simultaneous adsorption of $\mathrm{Cd}^{2+}$ and BPA on amphoteric surfactant activated montmorillonite. Chemosphere. 144 (8) 1026-1032. https://doi.org/10.1016/j.chemo sphere.2015.09.063

LIU S, WU P, CHEN M, YU L, KANG C, ZHU N and DANG Z (2017) Amphoteric modified vermiculites as adsorbents for enhancing removal of organic pollutants: bisphenol A and tetrabromobisphenol A. Environ. Pollut. 228 (2) 277-286. https://doi.org/10.1016/j.env pol.2017.03.082

LONG H, WU P, YANG L, HUANG Z, ZHU N and HU Z (2014) Efficient removal of cesium from aqueous solution with vermiculite of enhanced adsorption property through surface modification by ethylamine. J. Colloid Interf. Sci. 428 (2) 295-301. https://doi. org/10.1016/j.jcis.2014.05.001

LU N and LIU J (2010) Removal of phosphate and fluoride from wastewater by a hybrid precipitation-microfiltration process. Sep. Purif. Technol. 74 (3) 329-335. https://doi.org/10.1016/j.seppur. 2010.06.023

LÜRLING M and OOSTERHOUT F (2013) Controlling eutrophication by combined bloom precipitation and sediment phosphorus inactivation. Water Res. 47 (17) 6527-6537. https://doi.org/10.1016/j. watres.2013.08.019

LÜRLING M, WAAJEN G and OOSTERHOUT F (2014) Humic substances interfere with phosphate removal by lanthanum modified clay in controlling eutrophication. Water Res. 54 (1) 78-88. https:// doi.org/10.1016/j.watres.2014.01.059

MALANDRINO M, ABOLLINO O, GIACOMINO A, ACETO M and MENTASTI E (2006) Adsorption of heavy metals on vermiculite: Influence of $\mathrm{pH}$ and organic ligands. J. Colloid Interf. Sci. 299 (2) 537-546. https://doi.org/10.1016/j.jcis.2006.03.011

MCBRIDE M (1994) Environmental Chemistry of Soils. Oxford University, Oxford.

MEDEIROS M, SANSIVIERO M, ARAÚJO M and LAGO R (2009) Modification of vermiculite by polymerization and carbonization of glycerol to produce highly efficient materials for oil removal. Appl. Clay Sci. 45 (4) 213-219. https://doi.org/10.1016/j.clay.2009.06.008

MUIAMBO $\mathrm{H}$, FOCKE $\mathrm{W}$, ATANASOVA $\mathrm{M}$ and BENHAMIDA A (2015) Characterization of urea-modified palabora vermiculite. Appl. Clay Sci. 105 (1) 14-20. https://doi.org/10.1016/j.clay.2014.12.019

MÜNCH E and BARR K (2001) Controlled struvite crystallisation for removing phosphorus from anaerobic digester sidestreams. Water Res. 35 (1) 151-159. https://doi.org/10.1016/S0043-1354(00)00236-0

NA C and PARK H (2011) Applicability of theoretical adsorption models for studies on adsorption properties of adsorbents[II]. J. Kor. Soc. Environ. Eng. 33 (4) 804-811. https://doi.org/10.4491/KS EE.2011.33.11.804

NGUYEN T, NGO H, GUO W, LIANG S, LEE D, NGUYEN P and BUI X (2014) Modification of agricultural waste/by-products for enhanced phosphate removal and recovery: Potential and obstacles. Bioresour. Technol. 169 (3) 750-762. https://doi.org/10.1016/j.bior tech.2014.07.047

NING P, BART H, LI B, LU X and ZHANG Y (2008) Phosphate removal from wastewater by model-La(III) zeolite adsorbents. J. Environ. Sci. 20 (6) 670-674. https://doi.org/10.1016/S1001-0742(08)62111-7

OGATA F, IMAI D, TODA M, OTANI M and KAWASAKI N (2015) Adsorption of phosphate ion in aqueous solutions by calcined cobalt hydroxide at different temperatures. J. Environ. Chem. Eng. 3 (3) 1570-1577. https://doi.org/10.1016/j.jece.2015.05.028

OLADOJA N, OLOLADE I, ADESINA A, ADELAGUN R and SANI $Y$ (2013) Appraisal of gastropod shell as calcium ion source for phosphate removal and recovery in calcium phosphate minerals crystallization procedure. Chem. Eng. Res. Design. 91 (5) 810-818. https://doi.org/10.1016/j.cherd.2012.09.017

PELEKA E and DELIYANNI E (2009) Adsorptive removal of phosphates from aqueous solutions. Desalination. 245 (1) 357-371. https://doi. org/10.1016/j.desal.2008.04.050

PRADHAN J, DAS J, DAS S and THAKUR R (1998) Adsorption of phosphate from aqueous solution using activated red mud. J. Colloid Interf. Sci. 204 (1) 169-172. https://doi.org/10.1006/jcis.1998.5594 
RUIXIA L, JINLONG G and HONGXIAO T (2002) Adsorption of fluoride, phosphate, and arsenate ions on a new type of ion exchange fiber. J. Colloid Interf. Sci. 248 (2) 268-274. https://doi.org/10.1006/ jcis. 2002.8260

SAHA B, CHAKRABORTY S and DAS G (2008) A mechanistic insight into enhanced and selective phosphate adsorption on a coated carboxylated surface. J. Colloid Interf. Sci. 331 (1) 21-26. https://doi. org/10.1016/j.jcis.2008.11.007

SHIN E, HAN J, JANG M, MIN S, PARK J and ROWELL R (2004) Phosphate adsorption on aluminium-impregnated mesoporous silicates: surface structure and behavior of adsorbents. Environ. Sci. Technol. 38 (3) 912-917. https://doi.org/10.1021/es030488e

SONG J, LEE J, KIM S and LEE T (2009) Evaluation of removal properties of $\mathrm{Cu}(\Pi)$ from aqueous solutions by inflated vermiculites. J. Kor. Geo-Environ. Soc. 10 (1) 25-32 (in Korean).

SONG Y, YUAN P, ZHENG B, PENG J, YUAN F and GAO Y (2007) Nutrients removal and recovery by crystallization of magnesium ammonium phosphate from synthetic swine wastewater. Chemosphere. 69 (2) 319-324. https://doi.org/10.1016/j.chemosphere.2007. 06.001

SOUSA A, BRAGA T, GOMES E, VALENTINI A and LONGHINOTTI E (2012) Adsorption of phosphate using mesoporous spheres containing iron and aluminum oxide. J. Chem. Eng. 210 (1) 143-149. https://doi.org/10.1016/j.cej.2012.08.080

SUN X, IMAI T, SEKINE M, HIGUCHI T, YAMAMOTO K, KANNO $A$ and NAKAZONO S (2014) Adsorption of phosphate using calcined Mg3-Fe layered double hydroxides in a fixed-bed column study. J. Ind. Eng. Chem. 20 (5) 3623-3630. https://doi.org/10.1016/j. jiec.2013.12.057

TEKILE A, KIM I and KIM J (2015) Mini-review on river eutrophication and bottom improvement techniques, with special emphasis on the Nakdong River. J. Environ. Sci. 30 (1) 113-121. https://doi.org/ 10.1016/j.jes.2014.10.014

UNNITHAN M, VINOD V and ANIRUDHAN T (2002) Ability of Iron(III)-Loaded carboxylated polyacrylamide-grafted sawdust to remove phosphate ions from aqueous solution and fertilizer industry wastewater: Adsorption kinetics and isotherm studies. J. Appl. Polymer Sci. 84 (13) 2541-2553. https://doi.org/10.1002/app.10579

VAIOPOULOU E, MELIDIS P and AIVASIDIS A (2007) Growth of filamentous bacteria in an enhanced biological phosphorus removal system. Desalination. 213 (1) 288-296. https://doi.org/10.1016/j.desal. 2006.02.101
WEN Z, ZHANG Y and DAI C (2014) Removal of phosphate from aqueous solution using nanoscale zerovalent iron (nZVI). Colloids and Surfaces A. Physicochem. Eng. Aspects. 457 (3) 433-440. https:// doi.org/10.1016/j.colsurfa.2014.06.017

WOUMFO E, SIEWE J and NJOPWOUO D (2015) A fixed-bed column for phosphate removal from aqueous solutions using an andosolbagasse mixture. J. Environ. Manage. 151 (2) 450-460. https://doi. org/10.1016/j.jenvman.2014.11.029

YANG S, DING D, ZHAO Y, HUANG W, ZHANG Z, LEI Z and YANG Y (2013) Investigation of phosphate adsorption from aqueous solution using Kanuma mud: Behaviors and mechanisms. J. Environ. Chem. Eng. 1 (3) 355-362. https://doi.org/10.1016/j.jece.2013.05.016

YANG S, WU P, LIU J, CHEN M, AHMED Z and ZHU N (2018) Efficient removal of bisphenol A by superoxide radical and singlet oxygen generated from peroxymonosulfate activated with $\mathrm{Fe}^{0}$ montmorillonite. Chem. Eng. J. 350 (3) 484-495. https://doi.org/ 10.1016/j.cej.2018.04.175

YEOM S and JUNG K (2008) Recycling wasted scallop shell as an adsorbent for the removal of phosphate. J. Ind. Eng. Chem. 15 (1) 40-44. https://doi.org/10.1016/j.jiec.2008.08.014

YUAN M, CARMICHAEL W and HILBORN E (2006) Microcystin analysis in human sera and liver from human fatalities in Caruaru, Brazil 1996. Toxicon. 48 (6) 627-640. https://doi.org/10.1016/j.tox icon.2006.07.031

YU X, WEI C, KE L, HU Y, XIE X and WU H (2010) Development of organovermiculite-based adsorbent for removing anionic dye from aqueous solution. J. Hazardous Mater. 180 (1) 499-507. https://doi. org/10.1016/j.jhazmat.2010.04.059

ZENG L, LI X and LIU J (2004) Adsorptive removal of phosphate from aqueous solutions using iron oxide tailings. Water Res. 38 (5) 1318 1326. https://doi.org/10.1016/j.watres.2003.12.009

ZHANG L, WAN L, CHANG N, LIU J, DUAN C, ZHOU Q, LI X and WANG X (2011) Removal of phosphate from water by activated carbon fiber loaded with lanthanum oxide. J. Hazardous Mater. 190 (1) 848-855. https://doi.org/10.1016/j.jhazmat.2011.04.021

ZHONG B, STANFORTH R, WU S and CHEN J (2007) Proton interaction in phosphate adsorption onto goethite. J. Colloid Interf. Sci. 308 (1) 40-48. https://doi.org/10.1016/j.jcis.2006.12.055 